\title{
Experimental and computational fluid dynamics investigations of tracking CPC solar collectors
}

\author{
Yuan, Guofeng; Fan, Jianhua; Kong, Weiqing; Furbo, Simon; Perers, Bengt; Sallaberry, Fabienne
}

Published in:

Solar Energy

Link to article, DOI:

10.1016/j.solener.2020.01.090

Publication date:

2020

Document Version

Peer reviewed version

Link back to DTU Orbit

Citation (APA):

Yuan, G., Fan, J., Kong, W., Furbo, S., Perers, B., \& Sallaberry, F. (2020). Experimental and computational fluid dynamics investigations of tracking CPC solar collectors. Solar Energy, 199, 26-38.

https://doi.org/10.1016/i.solener.2020.01.090

\section{General rights}

Copyright and moral rights for the publications made accessible in the public portal are retained by the authors and/or other copyright owners and it is a condition of accessing publications that users recognise and abide by the legal requirements associated with these rights.

- Users may download and print one copy of any publication from the public portal for the purpose of private study or research.

- You may not further distribute the material or use it for any profit-making activity or commercial gain

- You may freely distribute the URL identifying the publication in the public portal 


\title{
Experimental and Computational Fluid Dynamics Investigations of tracking CPC Solar Collectors
}

\author{
Guofeng Yuan ${ }^{1,2}$, Jianhua Fan², Weiqing Kong ${ }^{2}$, Simon Furbo ${ }^{2}$, Bengt Perers ${ }^{2}$, Fabienne Sallaberry ${ }^{3,2}$ \\ 1. Key Laboratory of Solar Thermal Energy and Photovoltaic System, Institute of Electrical \\ Engineering, Chinese Academy of Sciences, Beijing 100190, PR China \\ 2. Department of Civil Engineering, Technical University of Denmark, Brovej 118, Kgs. Lyngby DK \\ 2800, Denmark \\ 3. CENER (National Renewable Energy Centre), Solar Thermal Energy Department, C/ Ciudad de la \\ Innovación, 7, 31621 Sarriguren (Navarra), Spain
}

\begin{abstract}
:
The aim of the paper was to investigate thermal performance of two newly developed $15.4 \mathrm{~m}^{2}$ compound parabolic concentrator (CPC) solar collectors both theoretically and experimentally. The two collectors are identical except that one collector is equipped with a transparent Ethylene tetrafluoroethylene (ETFE) foil and the other collector is not. Experimentally the solar collectors were tested in an outdoor test facility at different temperatures. Collector efficiencies were determined. Theoretically simplified CFD models of the CPC solar collectors were developed and validated against the measurements. A ray tracing tool Tonatiuh was used to calculate distribution of solar irradiance on the receiver. The influence of the ETFE foil on collector heat loss coefficient and efficiency was investigated. The results show that the CFD model predicts satisfactorily temperature rises of the collectors in the temperature range between $20^{\circ} \mathrm{C}$ and $81^{\circ} \mathrm{C}$. The deviations between the measured and the calculated temperature rises were limited to $\pm 0.3 \mathrm{~K}$ with a relative error $<3.7 \%$. By installation of the ETFE foil, the first order collector heat loss coefficient decreased from 1.42 to $0.82 \mathrm{~W} / \mathrm{m}^{2} / \mathrm{K}$. Efficiency of the collector with the ETFE foil was measured to be $63 \%, 55 \%$ and $54 \%$ for a
\end{abstract}

\footnotetext{
${ }^{*}$ Corresponding author. ISES member Tel: +45-45251889 Fax: +45-45883282

Email address: jif@byg.dtu.dk (Jianhua Fan)
} 
mean collector fluid temperature of $27^{\circ} \mathrm{C}, 63^{\circ} \mathrm{C}$ and $81^{\circ} \mathrm{C}$ respectively. For a solar irradiance of $895 \mathrm{~W} / \mathrm{m}^{2}$ and a mean collector temperature of $133^{\circ} \mathrm{C}$, collector efficiency is predicted to increase from $36 \%$ to $41 \%$ by installation of the ETFE foil. Another $5 \%$ increase of collector efficiency is expected if installation of the foil is made airtight.

\section{Keywords:}

Compound Parabolic Concentrator (CPC) solar collector, thermal efficiency measurements, CFD simulations, ray tracing, heat loss coefficient 


\section{Introduction}

Denmark is one of the leading countries in district heating. More than $60 \%$ of Danish buildings are connected to district heating and district heating covers more than $50 \%$ of the total heating demand of Denmark (Nussbaumer \& Thalmann 2014). Danish district heating is in the process of transition from current 3rd generation district heating to the future 4th generation low temperature district heating with a large share of renewable energies. By the end of 2016, more than 1.3 million $\mathrm{m}^{2}$ solar heating plants are in operation while there are 279,000 $\mathrm{m}^{2}$ solar heating plants being planned (Tian et al. 2017, Tian et al. 2018, Tian et al. 2018). Most of the solar collectors in the existing solar heating plants are typically flat plate collectors (FPC).

Fan and Furbo $(2007,2008)$ investigated heat transfer and fluid flow in a large flat plate solar collector designed for solar heating plants. The FPC is especially designed for district heating applications with operation temperatures in the range $40-95^{\circ} \mathrm{C}$. The collector is characterized by a maximum collector efficiency up to $83-85 \%$ and a heat loss coefficient as low as $3 \mathrm{~W} / \mathrm{m}^{2} / \mathrm{K}$. CFD calculations were carried out to investigate the influence of uneven flow distribution among the absorber tubes on collector efficiency and temperature distribution. Risk of local overheating was identified (Fan and Furbo 2007, 2008).

The operation temperature of solar collectors in solar heating plants in Denmark is typically in the range from about $40^{\circ} \mathrm{C}$ to $95^{\circ} \mathrm{C}$ (Tian et al. 2019). The efficiency of flat plate collectors decreases significantly in the range of $70^{\circ} \mathrm{C}-95^{\circ} \mathrm{C}$, while parabolic-trough collectors (PTC) and CPCs keep relatively high efficiency in the temperature range. It is therefore advantageous to use CPC and/or PTC in a solar district heating plant at relatively higher operation temperatures.

CPC collectors have been experimentally and numerically investigated in the literature. Winston (1974) developed a non-imaging CPC collector with a larger acceptance for diffuse light without diurnal tracking of the sun. The author concluded that the efficiency for diffuse radiation could be considered as the reciprocal of the concentration factor, which gives a good basis for comparison with a flat plate collector. Garrison (1979) developed an all glass vacuum collector tube which provides an optimum Winston concentration on the interior glass tube with a selective coating. Rabl and Winston (1979) investigated several practical problems in the design of solar collectors with CPCs. The design of the CPC was optimized with an increased collector efficiency by for instance a gap between receiver and reflector and a glass tube around the receiver. The optical efficiency and concentration factor have a big impact on the efficiency of the CPC, therefore numeric investigations were carried out to improve optical design of the CPCs using ray tracing methods. Khonkar et al. (1994) investigated the ray trace of a tubular absorber of a CPC based on AutoCAD and a Fortran program. The focus of the study was to investigate the location of the hot spots on the absorber. Jafrancesco et al. (2012) analyzed various methods to model an approximated CPC with an aim to identify simple and cost-effective methods. In addition to ray tracing modeling, computational fluid dynamics (CFD) was also successfully 
implemented by researchers in the design optimization of CPCs. Santos-González (2014) designed a CPC module with 12 collectors using a detailed one-dimensional numerical model and a ray tracing method. Experiments were carried out to test the CPC collector in operation temperatures between $30-60^{\circ} \mathrm{C}$ according to the Mexican standard NMX-ES-001-NORMEX-2005. Craig et al. (2016) evaluated the use of CFD to investigate the influence of solar irradiation on a concentrated solar collector without using the traditional raytracing methods. For all the test cases, good agreement was found when both ray-effect and false scattering errors were limited by using suitable modelling settings. Antonelli et al. (2016) analyzed heat losses from CPC collectors by CFD simulation. Correlations of Nusselt number on receivers were obtained based on the CFD simulations. The correlations were used to calculate heat loss of the receivers and to investigate the influence of different receiver designs. Recently alternative methods to reduce collector thermal loss other than evacuated tube were proposed and their thermal efficiency evaluated by validated CFD models (Francesconi et al 2018).

Investigations were also carried out to integrate CPC collectors with heat storages for domestic heating and industrial process heating applications. Devanarayanan et al. (2014) presented up to date development in integrated collector storage water heater using CPC collector, and different designs of the CPCs were reviewed. A CPC solar water heater with integrated heat storage was investigated by Varghese and Manjunath (2017). A maximum collector efficiency of $38 \%$ was measured. A two phase solar water heater with thermosiphon was experimentally investigated by Esen M. and Esen H. (2005). New designs of CPCs were also developed to improve overall collector efficiencies. Abdullahi et al. (2015) investigated the potential benefits by using either two tubular receivers or an elliptical single receiver in one concentrator. By means of advanced ray tracing technique, optical efficiency of a CPC with two tubular receivers aligned horizontally and vertically was predicted. Zheng et al. (2016) presented a new type of serpentine CPC solar collector, which was a combination of a flat plate solar collector and a CPC solar collector. The experimental results showed that thermal efficiency of the collector could be as high as $60.5 \%$ for a collector fluid inlet temperature of $30^{\circ} \mathrm{C}$ and a solar irradiance of approx. $800 \mathrm{~W} / \mathrm{m}^{2}$. An extensive review of the applications of CPCs for domestic and industrial process heating was presented by Pranesh et al (2019). Investigations carried out for the past 50 years were included. The potential to increase its application in the future was identified. Kumar et al. (2019) summarized the developments of solar heating technologies for industrial process. The future prospects for CPCs were discussed. As examples of recent developments, the use of CPCs were extended to photovoltaic, PVT, heat pump/refrigeration applications, power generation and even a solar still. Umair et al. (2014) simulated a solar adsorption refrigeration system, in which a wing type CPC was presented and tested. Antonin et al. (2013) described CPC designs as primary concentrators for concentrating photovoltaic (CPV) applications. Both 2D and 3D CPC structures were evaluated and some particular solutions were selected for possible photovoltaic applications. Atheaya (2016) designed a glazed and an unglazed inverted absorber partially covered by photovoltaic thermal compound parabolic concentrator (PVT-CPC). The performance of proposed systems 
was tested. Feng et al. (2015) developed a new multifunctional PV/T/D solar energy system for building roofs. Experiments were carried out to measure the PV efficiency and air heating power of the system under outdoor conditions. Arunkumar (2016) developed a CPC assisted tubular solar still and the systems performance were determined for different configurations. A non-tracking external compound parabolic concentrator (XCPC) was investigated for $200^{\circ} \mathrm{C}$ applications by Widyolar et al. (2018). A collector efficiency of $50 \%$ was achieved at $200^{\circ} \mathrm{C}$. Cioccolanti et al (2019) developed a small scale combined cooling, heating and power system. The investigated system consisted of an Organic Rankine Cycle (ORC) generator of $3.5 \mathrm{kWe}$, a $17 \mathrm{kWc}$ absorption chiller, a $3 \mathrm{~m}^{3}$ oil storage tank and a $50 \mathrm{~m}^{2} \mathrm{CPC}$ solar collector field. Life cycle assessment (LCA) of the system was concluded to be extremely important. Tian et al. (2018) presented an extensive review of designs, applications, recent technological developments for CPCs. Special focuses was put on investigations since 2000.

However, there is a lack of detailed investigations on large scale CPCs for district heating applications. Since CPC collectors can accept incoming solar irradiance over a relatively wide range of angles, most of the CPC collectors investigated in the aforementioned literature were stationary. Madala and Boehm (2017) presented an extensive review of the available non-imaging concentrating mechanisms with stationary applications in mind and identified economic benefits of stationary CPC solutions. But for district heating applications, the operation temperatures of the collector can be as high as $80-95^{\circ} \mathrm{C}$. Tracking of the collector, although rough and intermittent, could be desirable. A quasi stationary non-imaging CPC collector was developed for industrial heating applications. The tilt of the collectors was adjusted seasonally which enables a better concentration without an expensive tracking system. Osório et al. (2019) developed an optimization method based on levelized cost of heat for CPC collectors.

A new type of tracking CPC collector has been developed by PolyCSP ApS for solar heating plants. The design of the CPC collector is especially optimized for the temperature range of $90-160{ }^{\circ} \mathrm{C}$. The basics of the CPC collector is the new "POLYCSP" absorber tubes in combination with multi-parabolic receivers, all integrated in a robust flat panel design (Sallaberry et al. 2017). The collector panel is placed on a tracker that adjusts the tilt of the collector to track the sun on one axis and that an ETFE foil is installed around the absorber tube to minimize convective heat loss. Inside the metal absorber tube there is a metal tube with a smaller diameter. Collector fluid is circulated through the annulus in between the two co-axial tubes. The aim of the design is to increase the convective heat transfer between the absorber and the collector fluid by increasing fluid velocities and creating turbulence in the tube (Kong et al. 2019). At the same time the CPC collector enables higher operating temperatures and higher total energy output similar to the more costly PTC and Linear Fresnel Reflector (LFR) collector, however with the robustness and simplicity similar to the conventional flat plate panels.

The aim of the paper is to investigate thermal performance of the novel tracking CPC collectors both 
experimentally and theoretically. Experimentally the newly developed CPC collectors were tested for the first time in an outdoor test facility in the test facility of the Technical University of Denmark. Detailed measurements were carried out to determine temperature increases and collector efficiencies under different operation conditions. The measured collector efficiencies and temperatures were compared to the calculated ones using simplified CFD models of the CPC collectors. Validity of the newly developed CFD models was elucidated. The validated CFD model was then used to predict collector efficiency at higher temperatures above the limit of the test facility. An expression of efficiency for the CPC collector was then determined based on the CFD calculated efficiencies. The investigation brought new knowledge on the influence of collector efficiency and heat loss coefficient by installation of the ETFE foil. The advantage and disadvantage of the tracking CPC collectors versus flat plate solar collector were also elucidated.

\section{Experimental setup}

\subsection{Collector description}

The $15.4 \mathrm{~m}^{2}$ PolyCSP CPC solar collectors were tested at the test facility of the Technical University of Denmark in September 2016, see Fig. 1. In the test platform two collectors were tested side by side. The two collectors were identical except that one of the collectors is equipped with a transparent ETFE (Ethylene tetrafluoroethylene) foil (the collector to the right in Fig. 1) and the other collector is not (the collector to the left in Fig. 1). The solar collectors are designed and manufactured by the Danish company PolyCSP ApS for medium and large solar heating systems. The collector consists of four identical CPC troughs with a width of $0.616 \mathrm{~m}$ and a length of $5.9 \mathrm{~m}$. Fig. 2 shows a view of the collector panel from the side. The gross area and the aperture area of the collector are $15.4 \mathrm{~m}^{2}$ and $13.9 \mathrm{~m}^{2}$ respectively. The CPC troughs are covered by a glass cover at the front and insulated by mineral wool at the back. The parabolic shaped reflector concentrates solar rays on a metal tube with selective coating on the outer surface of the tube. The outer diameter and wall thickness of the tube are $48 \mathrm{~mm}$ and $2 \mathrm{~mm}$ respectively. Inside the outer tube there is another metal tube with an outer diameter of $40 \mathrm{~mm}$. In the annulus between the two metal tubes a propylene glycol water mixture is circulated to remove heat from the tube wall. In the collector with ETFE foil, a transparent ETFE foil is installed around the metal tube. The collector is oriented in the East-West direction. The whole collector panel is placed on a one-axis tracker that automatically adjusts the tilt of the collector panel to track the sun. 

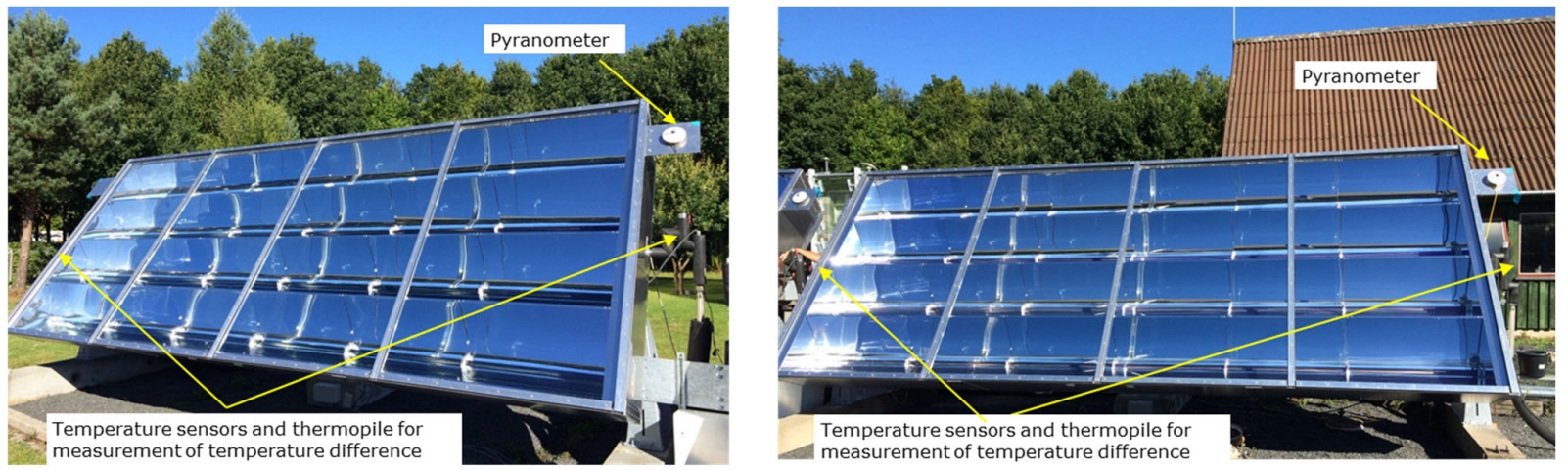

Fig. 1 Photo of the tested tracking CPC solar collectors (left: collector without ETFE foil, right: collector with ETFE foil)

A

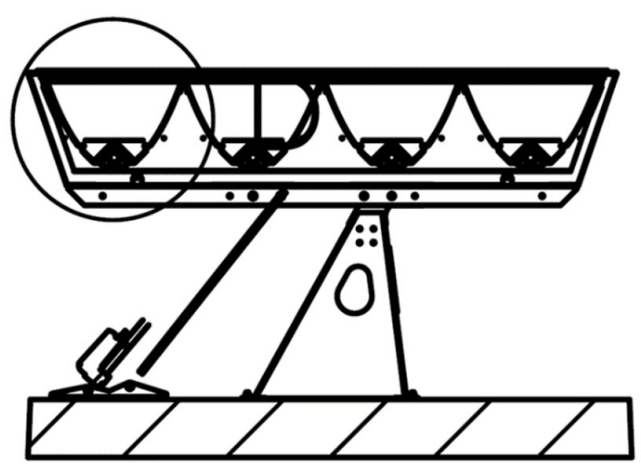

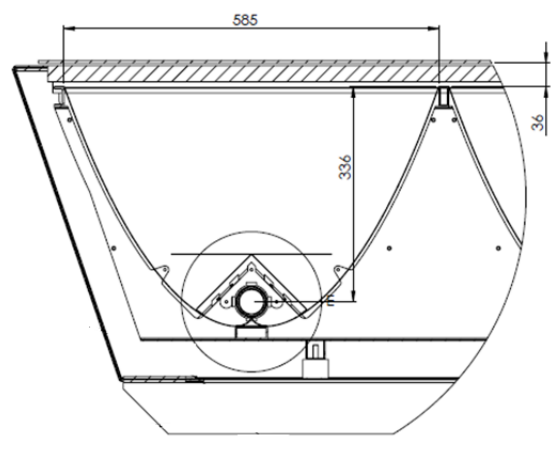

B

Fig. 2 A schematic illustration of the collector panel design (B: a magnified view of the cross section)

\subsection{Test platform and test conditions}

Fig. 3 shows a schematic diagram of the test rig. The collectors were tracking the sun in the transversal direction of the tube during the tests. The tracking accuracy set in the controller software during the test was $5^{\circ}$. The collector fluid was pumped through the solar collectors with a fluid flow rate of approx. $11 \mathrm{l} / \mathrm{min}$ constantly, corresponding to $0.71 \mathrm{l} / \mathrm{min}$ per $\mathrm{m}^{2}$ solar collector. The flow rate was chosen as specified by the manufacturer. The fluid inlet temperature was regulated by an electric heating element and a water cooling device to make sure that it can be adjusted during the test. The circulation flow rate was measured by Clorius flow meter with an accuracy of $1 \%$. Absolute temperatures were measured with Copper-constantan thermocouples (type TT) while the difference between the solar collector fluid inlet and outlet temperatures was measured with a copper-constantan thermopile type TT. Solar irradiance on the collector panels was measured using a pyranometer type CM11 from Kipp \& Zonen. The accuracy of the measuring equipment is given in Table 1. All the data inclusive the total irradiance $\left(G_{t}\right)$, the diffuse irradiance $\left(G_{d}\right)$ on the collector plane, the ambient temperature $\left(T_{a}\right)$, the fluid inlet and outlet temperature $\left(T_{f i}\right.$ and $\left.T_{f o}\right)$ and the fluid flow rate $(\dot{m})$ were recorded by a data logger. The time interval of data acquisition was $10 \mathrm{~s}$. 


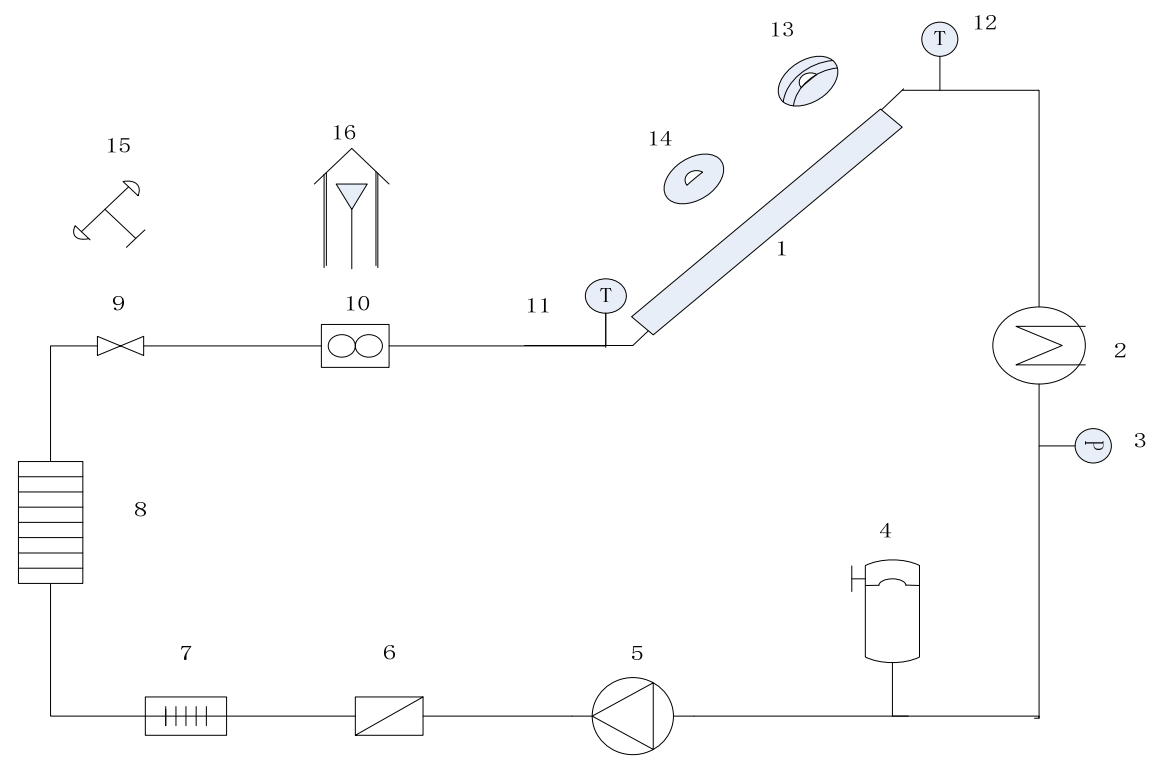

A list of the components in the test rig

\begin{tabular}{clcl}
\hline No. & Facility & No. & Facility \\
\hline 1 & Solar collector & 9 & Flow control valve \\
2 & Primary temperature regulator & 10 & Flow meter \\
3 & Pressure gauge & 11 & Inlet temperature sensor \\
4 & Expansion tank & 12 & Outlet temperature sensor \\
5 & Pump & 13 & Pyranometer with shadow band \\
6 & Filter & 14 & Pyranometer \\
7 & Electric heater & 15 & Anemometer \\
8 & Secondary temperature regulator & 16 & Ambient temperature sensor \\
\hline
\end{tabular}

Fig. 3 The test rig schematic

Three test periods of $15 \mathrm{~min}$ each at three inlet temperatures were chosen for experimental verification. Each test period was in steady state test condition according to the collect test standard ISO9806:2013.

\section{The numeric method}

\subsection{The simplified CFD model of the collectors}

Thermal performance of the CPC solar collector panels was investigated numerically by CFD simulations. Two simplified CFD models of the collectors were built using Ansys Fluent 17.0 (Ansys Fluent, 2016): one for the collector with the ETFE foil and one for the collector without the foil. Preliminary investigations indicated that there were even flow distributions among the four identical CPC troughs, therefore periodic thermal condition for the trough was assumed. The collector panel could be simplified to one CPC trough with 
a periodic boundary condition on both sides of the trough, see Fig. 4 A. The dimension of the trough was 5900 $\mathrm{mm}$ long, $616 \mathrm{~mm}$ wide and $458 \mathrm{~mm}$ tall, which was the same as for the tested collector. In this way computing time consumption can be significantly reduced without sacrificing validity of the model. The CFD model included the parabolic reflector, the metal receiver tube with a wall thickness, the glass cover at the front and insulation material at the back, therefore the CFD model was able to calculate not only air movement in the solar collector panel but also the turbulent water flow in the absorber tubes, see Fig. 4 B. In term of heat transfer, the conjugate heat transport between fluid and solid material, the convective heat transport in fluid regions and thermal radiation were calculated in the CFD model. Fig. $4 \mathrm{~B}$ show cross section of the collector trough model without ETFE foil while Fig. $4 \mathrm{C}$ shows a magnified view of the cross section of the collector trough with the foil. The foil is placed around the receiver tube with both edges hung flexibly on the mirror through several support points. There are two gaps of around $5 \mathrm{~mm}$ in between the edges of the foil and the mirror. Solar collector fluid enters in the annulus at one end of the receiver tube and leaves the collector at the other end of the receiver tube. The absorbed solar energy determined by Equation 5 will be used as heat flux input on the outer surface of the receiver tube.
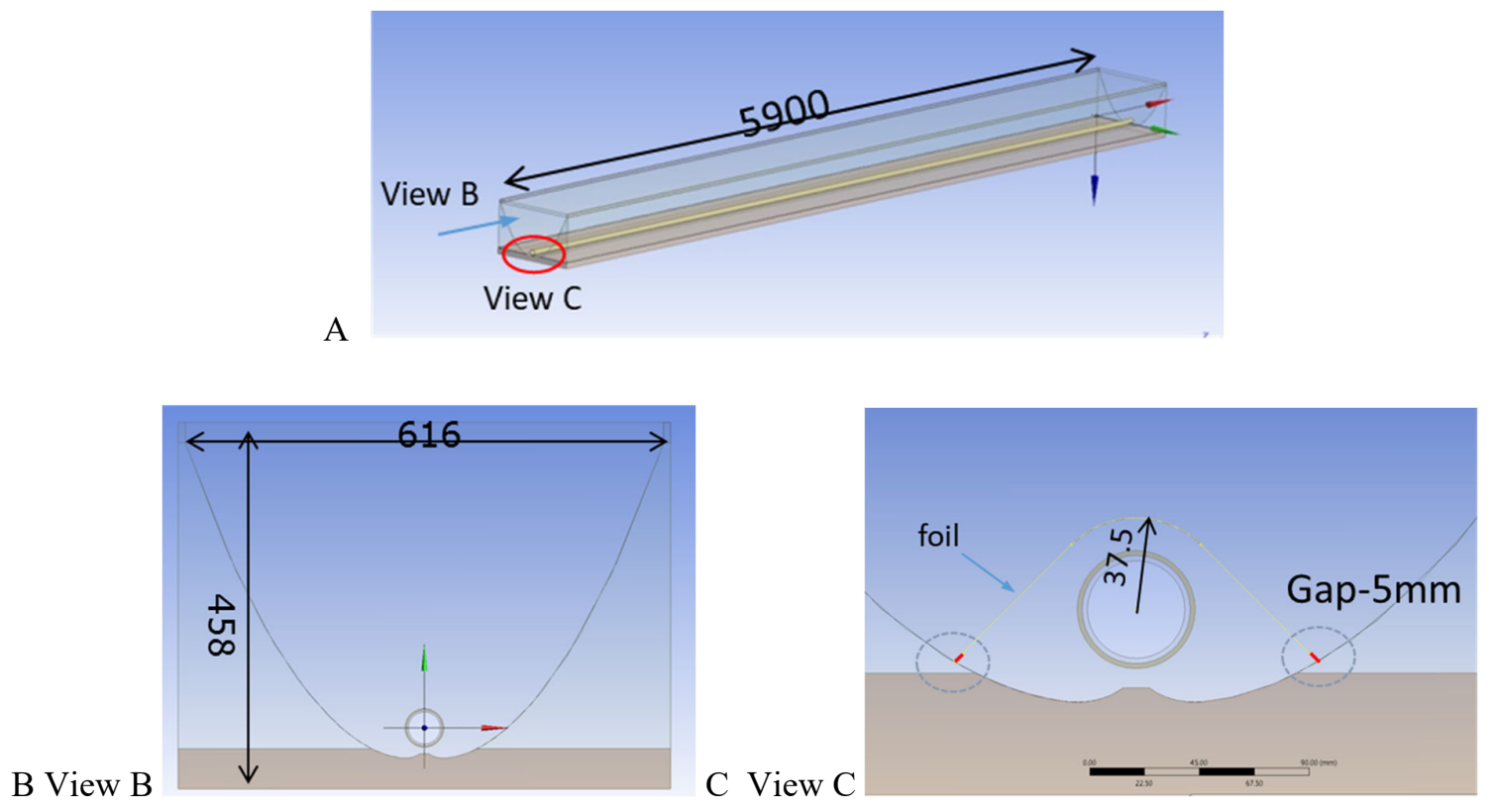

Fig. 4 The simplified CFD models of the CPC solar collectors (view B: cross section view of the trough without ETFE foil, View C: a magnified view of the cross section of the collector with ETFE foil)

A hexahedron mesh was created to discretize the computational domain. Due to the large difference in the dimension of the tube length $(5900 \mathrm{~m})$ and the tube diameter $(48 \mathrm{~mm})$, a fine grid distribution was needed in the cross section of the tube. As an example, Fig. 5 shows a cross section view of the mesh of the model with ETFE foil. Since heat transfer and mass flow in the annulus have a significant influence on thermal 
performance of the collector, refined boundary layer mesh was created along the wetted perimeters of the tubes. Refined boundary layer mesh was also applied on the outer surface of the outer tube and both sides of the reflector in order to capture air movement and heat transfer close to these surfaces. As a larger temperature gradient was expected close to the glass cover, the mesh close to the glass cover was refined. A refined boundary layer mesh was also applied to the foil and the gaps for the collector with ETFE foil, see Fig. 5. In the longitudinal direction of the tube there were 100 mesh divisions. The mesh scheme results in 1.32 million hexahedron cells for the collector without ETFE foil and 1.83 million cells for the collector with ETFE foil. A grid dependent study of the CFD model shows that an increase of the mesh density of the manifolds does not influence the prediction of calculated efficiency significantly.

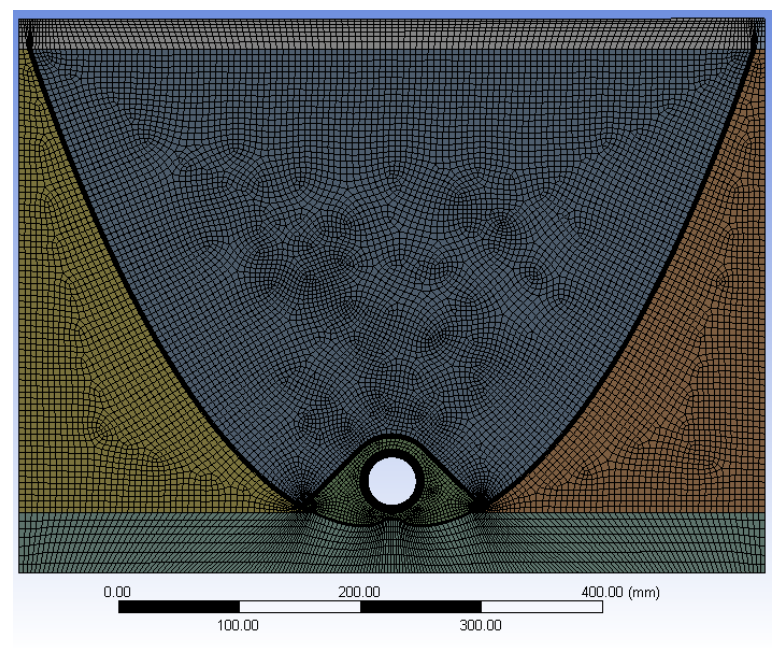

Fig. 5 Cross section view of the mesh of the collector with ETFE foil

\subsection{The boundary conditions}

On both sides of the CPC trough a periodic boundary condition is applied. All external surfaces of the trough are assigned a non-slip wall condition with designated external heat loss coefficients. The external heat loss coefficient depends strongly on wind conditions around the collector panel. Based on the measured wind speeds during the tests a heat transfer coefficient of $8.8 \mathrm{~W} / \mathrm{m}^{2} / \mathrm{K}$ is used as input in the CFD model (Morrison, 2001). The measured ambient air temperature is used as free stream temperature for the external surfaces of the collector panel.

Long wave radiation heat transfer inside the collector panel is calculated by a surface to surface radiation model. The emissivity of the absorber surface is 0.1. The reflector is made of Almeco VSP 295 aluminum plates produced by Almeco Group with an emissivity of 0.2 . The radiation heat transfer between the front glass cover and the sky is calculated. Typically sky temperatures $(15 \mathrm{~K}$ lower than the measured ambient air temperature) were used in the calculations (Morrison, 2001). The emissivity of the glass cover and the ETFE 
foil are 0.88 and 0.58 respectively.

Thermal conductivity of the insulation material is $0.045 \mathrm{~W} / \mathrm{m} / \mathrm{K}$. The propylene glycol water mixture has a glycol concentration of $40 \%$ by weight. Material properties of the mixture depends strongly on temperature of the fluid, as shown in the following equations (Furbo, 1997).

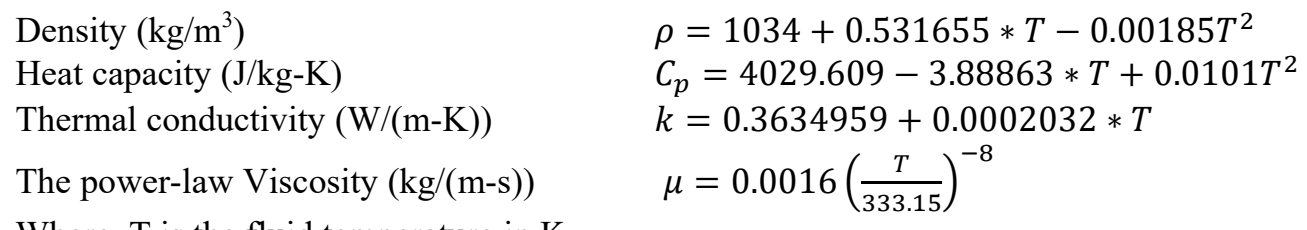

Where, $\mathrm{T}$ is the fluid temperature in $\mathrm{K}$.

The tilt angle of the collector was considered by specification of gravity vector in the CFD models. Since the collector efficiency was tested at noon when the change of tilt angle was the smallest of the day, the variation of tilt angle was within $\pm 5^{\circ}$ during one test with a duration of typically less than $1 \mathrm{hr}$. An average tilt angle was used in Fluent for validation against the measurements. For validation against tests carried out in different days, the tilt angles were slightly different, for example the tilt angle was in average $51.3^{\circ}$ for the tests on September 12 and 13, while it was in average $56^{\circ}$ for the test on September 25. Therefore, these average tilt angles were used in the respective CFD models.

Since the water flow in the annulus between the tubes and the air flow inside the collector panel fall in the turbulent region, standard k- $\varepsilon$ turbulence model is used in the CFD calculations. Since the length of the receiver tube $(5.9 \mathrm{~m})$ is much larger than the diameter of the inlet opening $(0.048 \mathrm{~m})$, distribution of velocity in the inlet opening wont have a significant influence on flow inside the receiver tube, therefore an uniform velocity inlet boundary condition is applied on the inlet to the collector. An outflow boundary condition is used on the outlet from the collector. Steady state condition was assumed for the CFD simulations since the collectors were tested according to ISO 9806:2013 under steady state. Since the product of thermal expansion coefficient of the collector fluid and temperature difference in the collector is in the magnitude of $10^{-3}-10^{-2}$, Boussinesq approximation is used for buoyancy modelling. The PRESTO and second order upwind method were used respectively for the discretization of the pressure and the momentum equations. The SIMPLE algorithm is used to treat the pressure-velocity coupling (Ansys Fluent Inc. 2016). The simulations start from an initial condition where there is a zero velocity and a uniform temperature over the computational domain. The solution is considered convergent if the scaled residual for the continuity equation, the momentum equations and the energy equation are less than $1.0 \times 10^{-4}, 1.0 \times 10^{-4}$ and $1.0 \times 10^{-7}$ respectively. One typical simulation takes approximately 12 hours for a parallel computing computer with eight $3 \mathrm{GHz}$ CPUs.

\subsection{Solar ray-tracing and distribution of solar intensity on the absorber tube}


The CFD model considers the conductive heat transfer of absorbed solar energy along the absorber tube and from the absorber tube to the solar collector fluid in the tube, as well as the heat losses to the air in the collector panel. The absorbed heat by the absorber surface, $\mathrm{I}_{\text {tube, }}$, is determined by the following equation in $\mathrm{W} / \mathrm{m}^{2}$ :

$$
I_{\text {tube }}=\left(G_{b}+G_{d} / F\right) \tau_{\text {glass }} \tau_{\text {foil }} \rho_{\text {cpc }} \alpha_{\text {tube }} C_{\text {acc-opt }} A_{\text {collector }} / A_{\text {absorber }}
$$

where $\left(G_{b}+G_{d} / F\right)$ is the total utilized solar radiation on the collector panel. An utilization ratio of diffuse radiation, 1/F, is used (Winston R. 1974; Welford W.T., Winston R., 1978). $\mathrm{G}_{\mathrm{b}}$ is the beam solar irradiance in $\mathrm{W} / \mathrm{m}^{2} ; \mathrm{G}_{\mathrm{d}}$ is the diffuse solar irradiance in $\mathrm{W} / \mathrm{m}^{2} ; \mathrm{F}$ is the concentration factor of the collector, approx. $4[-]$; $\tau_{\text {glass }}$ is transmittance of the glass cover, $0.95[-] ; \rho_{\mathrm{cpc}}$ is reflectance of the CPC surface, $0.93[-]$; $\alpha_{\text {tube }}$ is the absorptance of the selective coating surface, $0.92[-] ; \mathrm{C}_{\text {acc-opt }}$ is the optical correction coefficient taking into account surface accuracy of the CPC surface and tracking errors, [-]. The optical correction coefficient was estimated to be 0.85 for the investigated $\mathrm{CPC}$ solar collector. $\mathrm{A}_{\text {collector }}$ and $\mathrm{A}_{\mathrm{absorber}}$ are the transparent area and the absorber surface area of the collector respectively, $\mathrm{m}^{2}$. In the case of the collector with ETFE foil, transmittance of the foil, $\tau_{\text {glass }}$, is considered, $0.98[-]$.

Due to automatic tracking of the collector panel, the incidence angle of solar ray during the test at noon will be close to zero. Therefore, incidence angle modifier is not present in Equation 5.

Distribution of the beam irradiance on the absorber tube is determined by a ray tracing analysis of the CPC solar collector. The ray-tracing technique is an optical tool used for refracting and reflecting surfaces, which evaluates optical performance of a concentrator in order to determine distribution and intensity of sun rays on the receiver. The ray-tracing tool Tonatiuh is used in this paper. Tonatiuh is an open source Monte Carlo ray tracer for the optical simulation of solar concentrating systems (Blanco M.J. 2005, 2011). It simulates incidence and reflection of sun rays and quantifies the energy flux that reaches the receiver surface. In order to quantify the amount of energy losses by CPC truncation, a simulation with Tonatiuh was conducted with the truncated and non-truncated final designs. The inputs in the Tonatiuh analysis are shown in Table 2. In the analysis the reflectance of the receiver surface is configured as close to the reality as possible. The tilt of the CPC solar collector is considered in the calculation. The tracking error of the CPC solar collector (approx. 5 degrees) is not considered in the ray tracing analysis, but in Equation 5 the influence of tracking error on solar irradiance on the receiver tube is considered by the optical correction coefficient, $\mathrm{C}_{\text {acc-opt }}$.

\section{Results and discussion}

\subsection{Beam solar radiation intensity and temperature distribution on the absorber surface}

Fig. 6 shows distribution of the beam solar irradiance on the receiver surface of the collector without ETFE 
foil with a total solar irradiance of $895 \mathrm{~W} / \mathrm{m}^{2}$ and a diffuse radiation of $95 \mathrm{~W} / \mathrm{m}^{2}$. The incidence angle was very close to be zero in the tests at noon as the collector tracks the sun automatically by adjusting tilt of the collector panel. The $\mathrm{X}$ axis of the figure shows angle position on the receiver surface. The angle is determined by moving along the receiver perimeter in the clockwise direction with an angle of $0^{\circ}$ at the west direction. It is shown that the intensity of solar irradiance is quite low at the bottom of the receiver with an angle in between 167$360^{\circ}$. For an angle of $45-126^{\circ}$ the beam solar radiance lies in the range $750-990 \mathrm{~W} / \mathrm{m}^{2}$, indicating that the top receiver surface receives only one sun. The focus of the CPC is on both sides of the receiver surface with an angle around 36 and $140^{\circ}$ respectively. The peak solar irradiance reaches $37700 \mathrm{~W} / \mathrm{m}^{2}$, corresponding to a concentration factor of 38. On average the concentration factor for the whole receiver surface is approx. 4.

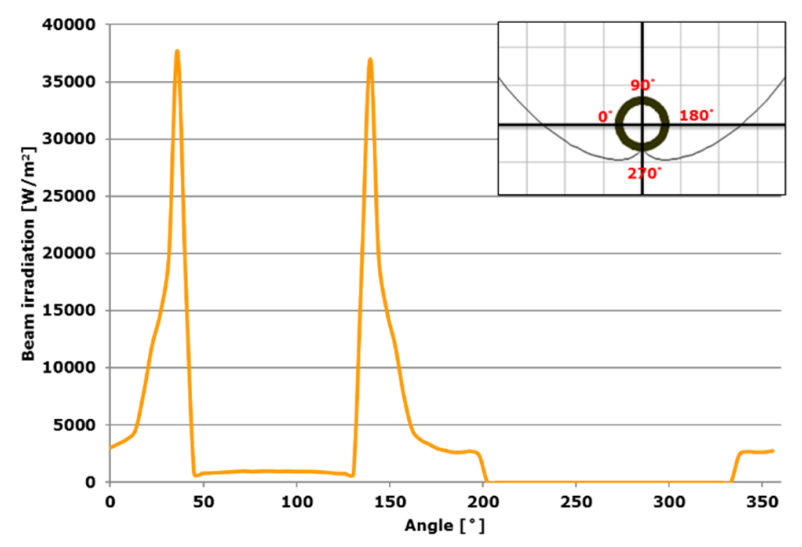

Fig. 6 Distribution of beam solar irradiance on the tube receiver surface of the collector without ETFE foil with a total irradiance of $895 \mathrm{~W} / \mathrm{m}^{2}$ and a diffuse radiation of $95 \mathrm{~W} / \mathrm{m}^{2}$.

Based on Fig. 6, the correlation between the solar intensity on the absorber surface $\mathrm{S}\left[\mathrm{W} / \mathrm{m}^{2}\right]$ and the angle $\theta\left[{ }^{\circ}\right]$ is determined by regression, as follows:

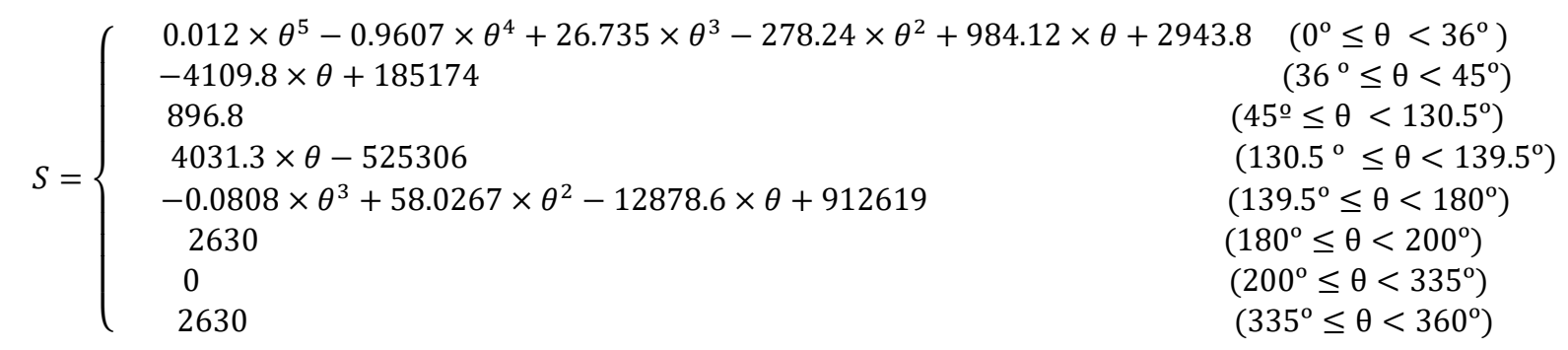

It should be noted that the equation 6 is only valid for an incidence angle of zero, which was the case during the collector tests at noon. The equation 6 will be used as input in the CFD model with an aim to validate the model against the collector tests. The relative standard deviation of the regression is approx. $7 \%$. Since the 
total solar irradiance on the receiver surface calculated by Equation 6 is exactly the same as the total solar irradiance shown in Fig. 6, a slightly different distribution pattern of solar irradiance will not make any significant influence on the calculated thermal performances of the collector.

With the beam solar radiation on the receiver surface, the inlet temperature of the collector and the ambient air temperature as inputs, the CFD model calculates the convective heat transfer between the receiver and the solar collector fluid, the conductive heat transfer along the receiver tube and the radiation and convective heat transfer between the receiver surface and the rest of the collector. Fig. 7 shows temperature distribution on the tube receiver surface of the collector without ETFE foil with a total irradiance of $895 \mathrm{~W} / \mathrm{m}^{2}$, a diffuse radiation of $95 \mathrm{~W} / \mathrm{m}^{2}$ and a mean solar collector temperature of $80.7^{\circ} \mathrm{C}$. Temperatures of the tube receiver surface are shown versus the angle at different distances from the inlet. The angle is determined by moving along the receiver surface in the clockwise direction from the furthest point to the left. The plot at $0.1 \mathrm{~m}$ from the inlet shows a lower temperature of around $76.5-77.5^{\circ} \mathrm{C}$ in the angles between $50-120^{\circ}$ and $180-360^{\circ}$, which corresponds well to the distribution pattern of the beam solar radiation on the receiver surface. The surface temperature could be lower than the inlet temperature of the collector $76.8^{\circ} \mathrm{C}$, due to cooling of the surface by convection and thermal radiation. There are two peaks of surface temperatures: one at an angle of $32-39^{\circ}$ and the other one at an angle of $140^{\circ}$. The surface temperatures at the two peaks are not symmetric due to the influence of buoyancy driven forces. Warmer fluid tends to rise up to the upper part of the receiver tube, increasing surface temperature at the angle of $140^{\circ}$.

With an increase of distance from the inlet, the peak temperatures of the receiver surface increase due to heating by concentrated solar radiation except in the area with an angle in between $220-336^{\circ}$. Since the beam solar radiation is very low in that part of the receiver surface, the surface temperature can be lower than the inlet temperature due to heat loss from the surface. At a distance of $1.5 \mathrm{~m}$ from the inlet, the lowest temperature of the receiver surface reaches $75^{\circ} \mathrm{C}$, which is $1.8 \mathrm{~K}$ lower than the inlet temperature.

At the point $5.8 \mathrm{~m}$ from the inlet $(0.1 \mathrm{~m}$ to the outlet), two peak temperatures can be seen around the receiver surface, $90.6^{\circ} \mathrm{C}$ at an angle of $32-39^{\circ}$ and $93.8^{\circ} \mathrm{C}$ at an angle of $140^{\circ}$. Although the peak of beam solar radiation at $36^{\circ}\left(37734 \mathrm{~W} / \mathrm{m}^{2}\right)$ is slightly higher than the peak at $140^{\circ}\left(37010 \mathrm{~W} / \mathrm{m}^{2}\right)$, the peak surface temperature at $32-39^{\circ}$ is $3.2 \mathrm{~K}$ lower than the peak surface temperature at $140^{\circ}$. It can be explained by the influence of buoyancy driven forces. The tilt of the collector was $51.3^{\circ}$ in the calculation. The gravity direction corresponds to the outgoing direction at an angle of $321.3^{\circ}$, as indicated as G in Fig. 7. Due to buoyance driven flow, warm fluid tends to rise up to the upper part of the tube (at an angle of $140^{\circ}$ ). The conjugate effect of the buoyancy driven force and the beam solar irradiance results in a higher surface temperature around an angle of $140^{\circ}$. A clear influence of buoyance driven force was observed even in the presence of turbulent flow. This could be explained by the relatively long time it takes for the fluid to pass through the tube. Since the length of the tube is 5.9 meter long and it takes more than $1 \mathrm{~min}$ for the collector fluid to flow from one end to the other end of 
the tube, the warmer fluid has time to rise up. Since the vertical dimension of the tube is as small as $0.048 \mathrm{~m}$, a slight vertical movement of the fluid will significantly influence temperature distribution in the cross section.

The results show that there is a significant temperature difference along the tube both in the axial and in the tangential directions of the tube, which could cause the risk of local boiling at the upper part of the tube close to the outlet of the collector. Another reason of the large temperature difference is the material property of the receiver tube. The receiver tube is made of stainless steel which has a lower thermal conductivity. If material with a higher thermal conductivity for example copper is used as material of the tube, the temperature difference along the tube would be smaller.

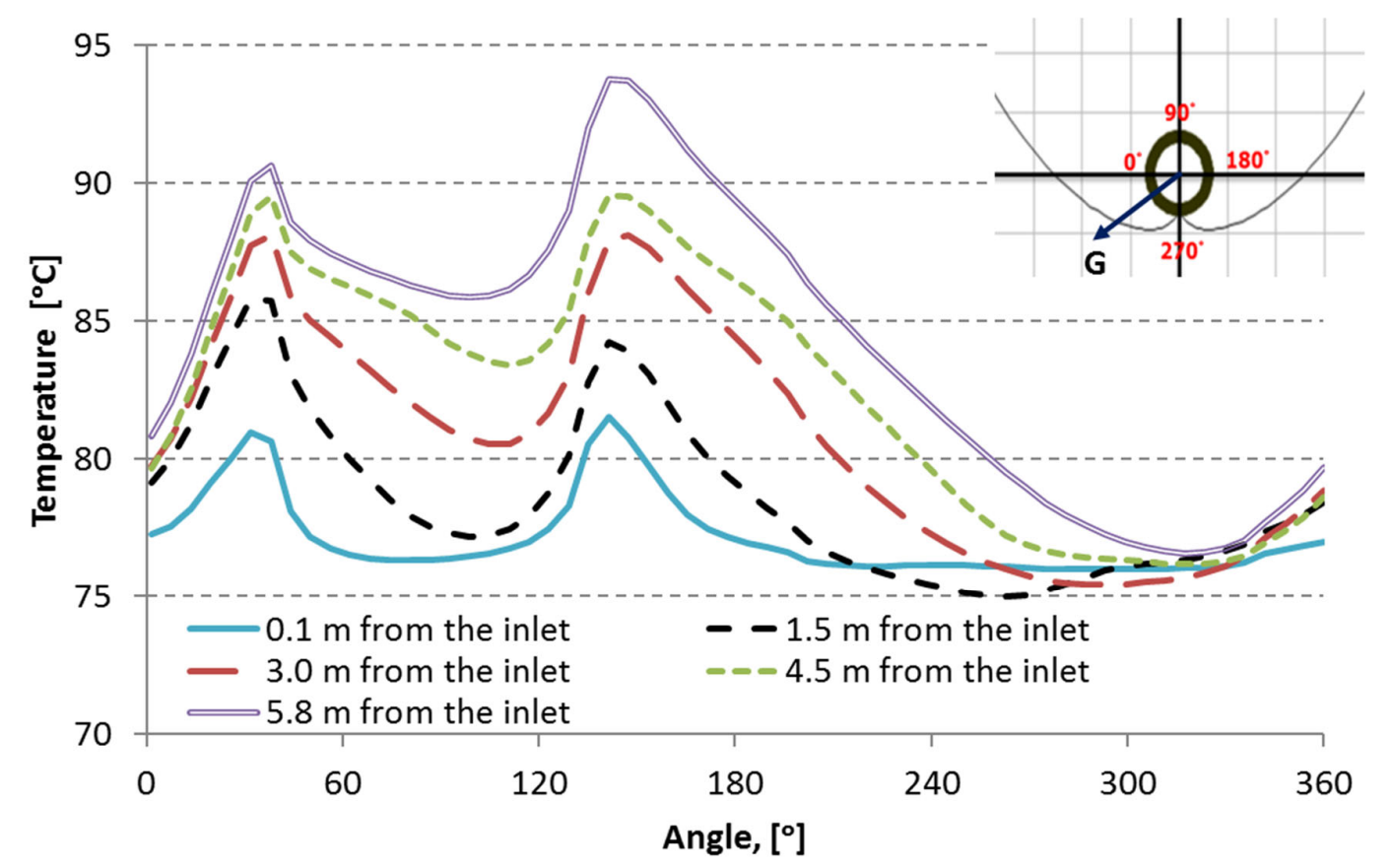

Fig. 7 Temperature distribution on the tube receiver surface of the collector without ETFE foil with a total irradiance of $895 \mathrm{~W} / \mathrm{m}^{2}$ and a mean solar collector temperature of $80.7^{\circ} \mathrm{C}$.

\subsection{Validation of the CFD model}

With the absorbed solar energy on the receiver surface and the ambient air temperature as inputs, the CFD model predicts the heat transfer and fluid flow in the collector panel. Consequently the temperature gain of the collector can be calculated. In order to validate the CFD model, detailed measurements were carried out on the outdoor test facility under different mean solar collector fluid temperatures. The measured temperatures were compared to the CFD calculated temperatures. A comparison between the measured and the CFD calculated temperatures of the collector without ETFE foil and of the collector with ETFE foil are shown in Table 3 and 
Table 4 respectively. The solar irradiances, the ambient temperature $T_{\mathrm{a}}$, the inlet $T_{\mathrm{fi}}$ and the outlet temperatures $\mathrm{T}_{\mathrm{fo}}$ of the collector fluid in Table 3 and Table 4 are measured values averaged over the test. Three temperature levels, namely $27^{\circ} \mathrm{C}, 63^{\circ} \mathrm{C}$ and $81^{\circ} \mathrm{C}$, were tested in the experiment. During the measurement a clear sky condition was observed. The total solar irradiance lies in the range $890-950 \mathrm{~W} / \mathrm{m}^{2}$ while the diffuse solar radiance varies between $60 \mathrm{~W} / \mathrm{m}^{2}$ and $110 \mathrm{~W} / \mathrm{m}^{2}$. The ambient air temperature was in the range $21-26^{\circ} \mathrm{C}$. Fig. 8 shows a comparison between the measured and the calculated temperature increases for both collectors. With an inlet temperature of $22^{\circ} \mathrm{C}$ and a corresponding mean solar collector fluid temperature of $27^{\circ} \mathrm{C}$, a temperature increase of $10.8 \mathrm{~K}$ was measured for the collector without ETFE foil while it was $10.5 \mathrm{~K}$ for the collector with ETFE foil. The collector without ETFE foil gives a temperature increase $0.3 \mathrm{~K}$ higher than that of the collector with ETFE foil. With a low mean temperature close to temperature of the ambient air, heat loss from the collector is limited, therefore the benefit of the ETFE foil is marginal. However, due to reflectance of the ETFE foil, though quite small, solar irradiance on the receiver tubes will be decreased, consequently efficiency of the collector with ETFE foil will be smaller compared to the collector without ETFE foil at lower operation temperatures. The benefit of ETFE foil is more obvious at high operation temperatures.

The CFD model predicts satisfactorily temperature increase of the collectors. As shown in Table 4, for an inlet temperature of $22^{\circ} \mathrm{C}$, the calculated temperature increase is $10.3 \mathrm{~K}$, corresponding to a difference of -0.2 $\mathrm{K}$ with the meausrement. With an increase of the inlet temperature to $59^{\circ} \mathrm{C}$ (mean temperature $63^{\circ} \mathrm{C}$ ), the temperature gain of the collector decreases to $8.5 \mathrm{~K}$. The CFD model overestimates the temperature increase by $0.2 \mathrm{~K}$. For an inlet temperature of $77^{\circ} \mathrm{C}$, the temperature increase was measured to be $7.7 \mathrm{~K}$. The difference between the CFD model and the measurement is only $0.1 \mathrm{~K}$. The deviation lies in the range $\pm 0.2 \mathrm{~K}$. Given the measurement accuracy of the thermopile sensor, the deviation can be considered marginal.

The relative errors of the CFD simulations are calculated to be 1.3-2.3\% for the collector with ETFE foil and 3.4-3.7\% for the collector without ETFE foil. The difference could be caused by the simplification of the model. Period boundary condition could be valid for the two interior troughs but it is not valid for the other two boundary troughs. However, the influence of the top and the bottom edge of the collector on collector heat loss could be considered insignificant because the air flow around the receiver tube is limited in the area enclosed by the reflector and the glass cover. Moreover the heat loss from the side of the collector is marginal due to good insulation of the edges. It can be concluded that the CFD model predicts satisfactorily the temperature increase of the collector. 

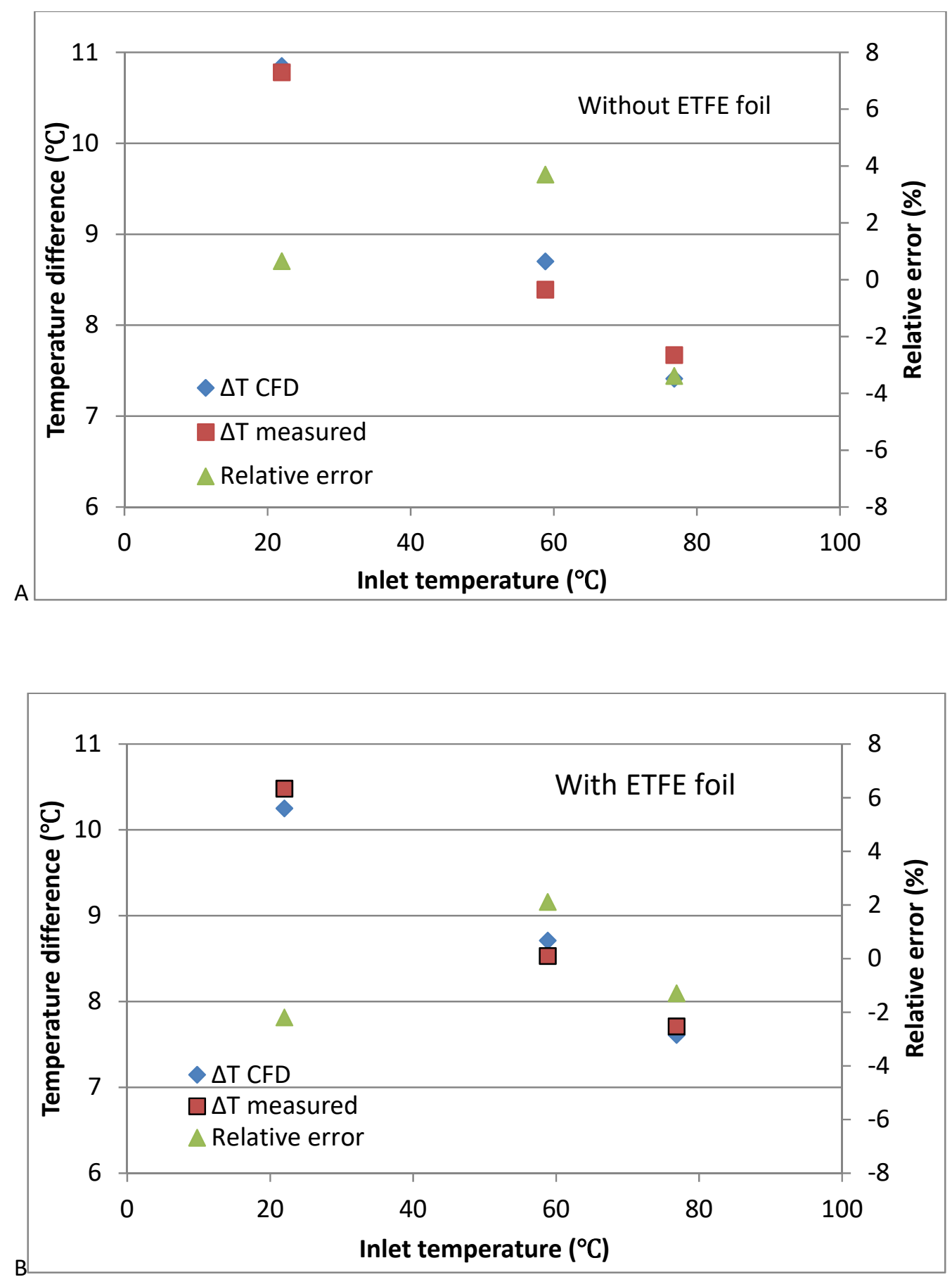

Fig. 8 Measured and CFD calculated temperature increases under different operation conditions for the collector without ETFE foil (A) and with ETFE foil (B).

\subsection{Heat loss coefficients of the collectors}

The ETFE foil was installed in the collector with an aim to decrease heat loss of the collector by minimizing convection flow around the receiver tuber. Measurement were carried out to investigate the influence of the 
ETFE foil on collector heat loss coefficients. Under steady state conditions during night, the heat loss from the collector will be equal to the measured cooling power of the collector fluid. The heat loss coefficients were determined by dividing the heat loss with temperature difference between the collector fluid and the ambient air. Fig. 5 shows measured and calculated heat loss coefficients of the collectors with an inlet temperature of approx. $79^{\circ} \mathrm{C}$. The tilt of the collector is $0^{\circ}$. The net heat loss coefficient of the collector without ETFE was measured to be $1.5 \mathrm{~W} / \mathrm{m}^{2} \mathrm{~K}$. The net heat loss coefficient was decreased by $0.4 \mathrm{~W} / \mathrm{m}^{2} \mathrm{~K}$ by installation of ETFE foil. The heat loss coefficients were also calculated by the CFD models. The calculations predicted a net heat loss coefficient of $1.7 \mathrm{~W} / \mathrm{m}^{2} \mathrm{~K}$ and $0.8 \mathrm{~W} / \mathrm{m}^{2} \mathrm{~K}$ respectively for the collector without and with the foil. The difference between the measurement and the simulation is within \pm 0.3 $\mathrm{W} / \mathrm{m}^{2} \mathrm{~K}$, corresponding to a relative error of $10-25 \%$. The large deviation could be caused by uncertainty of skype temperatures used in the CFD model, which have a significant influence on radiation heat loss of the collector. However, both the measurement and the calculation show a significant decrease of the collector heat loss coefficient by installation of the foil. As shown in Table 5, the heat loss from the cover was decreased by $0.8 \mathrm{~W} / \mathrm{m}^{2} \mathrm{~K}$ after installation of the ETFE foil, while heat loss coefficient from the rest of the collector was decreased by $0.1 \mathrm{~W} / \mathrm{m}^{2} \mathrm{~K}$. That proves the effect of the ETFE foil by trapping air around the receiver tube thus decreasing heat loss coefficient from the collector.

Fig. 9 shows the CFD calculated temperatures and velocity vectors on a plane perpendicular to the tube for the collector without ETFE foil. The section plane is located in the middle of the tube. Temperature plot on two interior $\mathrm{CPC}$ rows are obtained based on the calculation on one $\mathrm{CPC}$ row due to the period condition of the interior CPC collector row. In the calculation the total solar irradiance was $895 \mathrm{~W} / \mathrm{m}^{2}$. The inlet temperature of the collector and the ambient temperature were $77^{\circ} \mathrm{C}$ and $26^{\circ} \mathrm{C}$ respectively. The calculation shows that in the annulus between the tubes the fluid is heated by the absorbed solar energy to a temperature of around 80 ${ }^{\circ} \mathrm{C}$. Air around the tube is heated by the receiver surface, creating a rising air flow with a relatively higher temperature than the average air temperature in the collector panel. The uprising warm air reaches the CPC mirror surface and flows along the mirror surface up to the glass cover. There is a gap of $5 \mathrm{~mm}$ between the glass cover and the mirror. The uprising warm air flows along the glass cover upwards across the gas. Due to the periodic boundary conditions, there is also an uprising air flow at the lower gap between the glass cover and the mirror. An uprising flow along the glass cover can be seen in the area close to the glass cover, see Fig. 9B. The uprising flow along the mirror collides with the uprising flow along the glass cover, creating two circulations in the middle of the collector. 

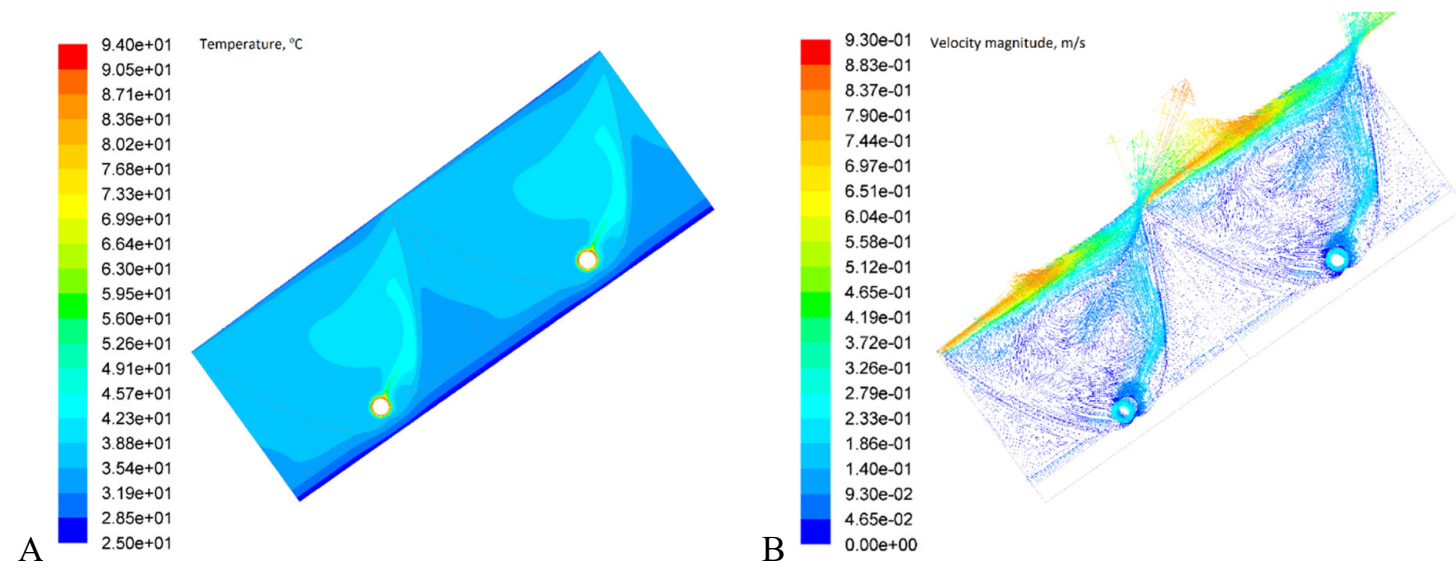

Fig. 9 CFD calculated temperatures (A) and velocity vectors (B) on the middle plane perpendicular to the tube for the collector without ETFE

After installation of the foil, the CFD calculated temperatures and velocity vectors on a plane perpendicular to the tube are shown in Fig. 10. The velocity vectors in Fig. 10 B clearly indicates a region with lower air speed around the receiver tube and a relatively larger circulation region in between the glass cover and the mirror. Due to the foil, a closed space is formed around the receiver tube, allowing air in it to heat up to a higher temperature. The air in between the glass cover and the mirror has a lower temperature compared to the collector without the foil, indicating a lower heat loss from the receiver tube.

The ETFE foil was installed in the collector by individual clasps that are fixed to the mirror. Due to the loose connection, gaps will be formed between the edges of the foil and the mirror. Existence of the gaps will cause leakage of air from the foil thus introducing loss of heat from the collector. Fig. 10 shows how the gap between the edges of the foil and the mirror influences fluid flow and temperature distribution in the collector. The gaps introduces a cross flow in the region around the receiver tube, therefore allowing part of the warm air to escape.
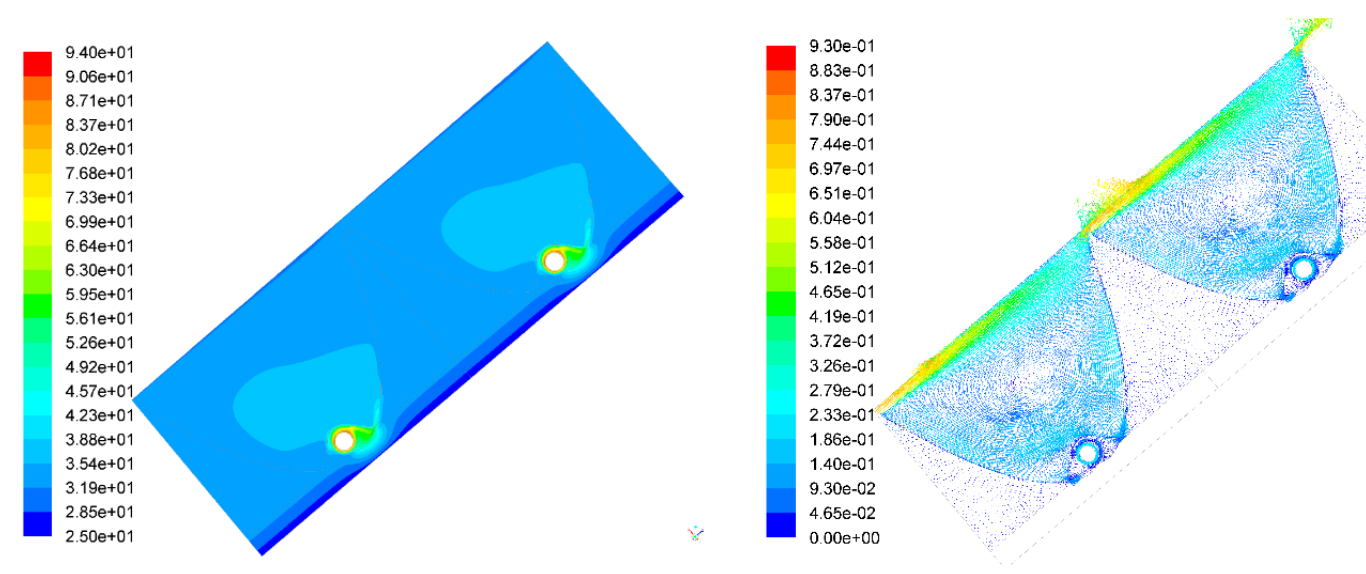
Fig. 10 calculated temperatures (A) and velocity vectors (B) on the middle plane perpendicular to the tube showing two interior $\mathrm{CPC}$ rows

CFD simulations were carried out to predict how the collector performance were influenced if the gaps were sealed. Table 6 shows a comparison of the calculated heat loss coefficients of the three collectors: the collector without foil, the collector with foil with gaps and the collector with foil with gaps closed. The net heat loss coefficient of the collector without foil is $2.0 \mathrm{~W} / \mathrm{m}^{2} \mathrm{~K}$, which is $0.2 \mathrm{~W} / \mathrm{m}^{2} \mathrm{~K}$ higher than the net heat loss coefficient in Table 5. The small deviation could be caused by variation of weather condition during the test, for instance, skype temperature, cloudiness. Even with gaps installation of the foil will decrease heat loss coefficient of the collector by half. With the gaps fixed, the heat loss coefficient could be further decreased by $0.2 \mathrm{~W} / \mathrm{m}^{2} \mathrm{~K}$, corresponding to a relative difference of $20 \%$.

\subsection{Collector efficiency}

By the measurement carried out in accordance with the ISO 9806:2013, efficiency of the solar collector based on collector aperture area was determined. Since the collector panel tracked the sun automatically, the incidence angle of solar ray during the test at noon can be considered to be zero. Table 7 shows measured and calculated efficiencies of the collector with ETFE foil with gaps at different mean solar collector fluid temperatures. The collector efficiency in Table 7 was obtained by an average of four measurement points carried out in one test condition. Each measurement point took $30 \mathrm{~min}$. The first $15 \mathrm{~min}$ steady state period was used as a prerequisite and the second 15 min steady state period was used to determine the efficiency. The efficiency tests were carried out at three temperature levels: $27.4^{\circ} \mathrm{C}, 63.2^{\circ} \mathrm{C}$ and $80.5^{\circ} \mathrm{C}$. Due to high risk of boiling in the test loop, a mean solar collector fluid temperature higher than $80.5^{\circ} \mathrm{C}$ was not attempted. The ambient temperature during the tests varied in the range $21-26^{\circ} \mathrm{C}$ while the solar irradiance on the collector surface fluctuated in the range between $895-940 \mathrm{~W} / \mathrm{m}^{2}$. As shown in Table 7, with a collector fluid mean temperature of $27.4^{\circ} \mathrm{C}$ and a collector flow rate of $2.761 / \mathrm{min}$ per tube, collector efficiency bases on aperture area was measured to be $63 \%$. With an increase of mean fluid temperature $\mathrm{T}_{\mathrm{m}}$ to $63.2{ }^{\circ} \mathrm{C}$ and $80.5^{\circ} \mathrm{C}$, the collector efficiency was decreased to $55 \%$ and $54 \%$ respectively. The measured collector efficiency was slight higher than the collector efficiency of $60.5 \%$ measured by Zheng et al. (2016) with a higher inlet temperature of $30^{\circ} \mathrm{C}$ and a slightly lower solar irradiance of approx. $800 \mathrm{~W} / \mathrm{m}^{2}$. The investigated CPC outperforms significantly the CPC solar water heater measured by Varghese and Manjunath (2017) with a maximum collector efficiency of $38 \%$, which could be explained by the relatively larger concentration ratio of the collector used in the present study (approx. 4) compared to a ratio of 2-3 used by Varghese and Manjunath.

Based on the outlet temperature predicted by the CFD model, collector efficiency was determined and compared to the measured results. The simulated collector efficiencies are in good agreement with the measured ones. For a collector mean temperature of $27.4{ }^{\circ} \mathrm{C}$ and $80.5^{\circ} \mathrm{C}$, the CFD model underestimated the 
collector efficiency by $1 \%$ and $1 \%$ respectively as shown in Fig. 7 . While for a mean collector fluid temperature of $63.2^{\circ} \mathrm{C}$ the CFD model overestimated the collector efficiency by $1 \%$ point. The relative error of the simulated collector efficiencies is within $\pm 2.3 \%$. Since the measurement uncertainty of collector efficiency is estimated to be around 2-5\%, the prediction accuracy of the CFD model can be considered satisfactory.

The validated CFD model was used to calculate collector efficiency at higher mean solar collector fluid temperatures. In the calculations it was assumed that there was no boiling of the collector fluid in the collector. The calculations were carried out for two mean solar collector fluid temperatures: $103.3^{\circ} \mathrm{C}$ and $132.6^{\circ} \mathrm{C}$. The CFD calculated collector efficiencies were plotted versus the modified temperature difference of the collector $\left(T_{m}-T_{a}\right) / G_{t}$, as shown in red squares in Fig. 11. $T^{*}$ is the modified temperature difference, defined as $\left(\mathrm{T}_{\mathrm{m}}-\mathrm{T}_{\mathrm{a}}\right) / \mathrm{G}_{\mathrm{t}}$. Collector efficiency expression was determined using regression based on the CFD predicted efficiencies. The efficiency expression based on collector aperture area for small incidence angles for the three collectors are calculated as follows:

Collector without ETFE foil

$\eta=0.635-1.561 *\left(\mathrm{~T}_{\mathrm{m}}-\mathrm{T}_{\mathrm{a}}\right) \boldsymbol{G}_{\mathrm{t}}-0.0067 *\left(\mathrm{~T}_{\mathrm{m}}-\mathrm{T}_{\mathrm{a}}\right)^{2} / \boldsymbol{G}_{\mathrm{t}}$

Collector with ETFE foil and with gaps

$\eta=0.602-0.907 *\left(\mathrm{~T}_{\mathrm{m}}-\mathrm{T}_{\mathrm{a}}\right) \boldsymbol{G}_{\mathrm{t}}-0.0058 *\left(\mathrm{~T}_{\mathrm{m}}-\mathrm{T}_{\mathrm{a}}\right)^{2} / \boldsymbol{G}_{\mathrm{t}}$

Collector with closed ETFE foil

$\eta=0.602-0.726 *\left(\mathrm{~T}_{\mathrm{m}}-\mathrm{T}_{\mathrm{a}}\right) \boldsymbol{G}_{\mathrm{t}}-0.0046 *\left(\mathrm{~T}_{\mathrm{m}}-\mathrm{T}_{\mathrm{a}}\right)^{2} / \boldsymbol{G}_{\mathrm{t}}$

$\mathrm{G}_{\mathrm{t}}$ is the total solar radiation on the collector in $\mathrm{W} / \mathrm{m}^{2}$, taking into account both the beam and the diffuse solar radiation. The total solar irradiance was used in order to facilitate comparison with flat plate solar collectors. $\mathrm{T}_{\mathrm{m}}$ is the mean solar collector fluid temperature, ${ }^{\circ} \mathrm{C} . \mathrm{T}_{\mathrm{a}}$ is the ambient air temperature, ${ }^{\circ} \mathrm{C}$. The peak collector efficiency of the collector is $64 \%$, which is lower than a typical flat plate solar collector, for instance, the Arcon HeatStore 35/10 as shown in Equation 10 (Tian et al. 2017) but the heat loss coefficients of the collector are much lower than that of the flat plate solar collector. A lower peak collector efficiency of the CPC solar collector could be explained by tracking error, surface accuracy of the reflectors and the incapability to utilize diffuse solar radiation, etc. A lower heat loss coefficients of the CPC collector is due to much smaller area of the absorber surface where heat is lost to the ambient, better insulation at the back of the panel and glass cover in the front of the panel.

By installation of the foil the peak collector efficiency was decreased to $60 \%$ but the first order heat loss was decreased 1 to $0.91 \mathrm{~W} / \mathrm{m}^{2} \mathrm{~K}$. The second order heat loss coefficient almost remains unchanged. As shown in 
Fig. 11, with a modified collector temperature $T^{*}$ smaller than $0.045 \mathrm{~K} \cdot \mathrm{m}^{2} / \mathrm{W}$, the collector without foil performs better than the collector with foil, because the gain of a lower heat loss by the foil is smaller than the loss by its lower transmittance. But for a higher temperature $\left(\mathrm{T}^{*}>0.045 \mathrm{~K} \cdot \mathrm{m}^{2} / \mathrm{W}\right)$, the collector with ETFE foil is definitely more efficient than the collector without foil. If the gaps in between the foil and the mirror are sealed, the collector first order heat loss coefficient can be further decreased by $0.18 \mathrm{~W} / \mathrm{m}^{2} \mathrm{~K}$. The second order heat loss coefficient was decreased from 0.006 to $0.005 \mathrm{~W} / \mathrm{m}^{2} / \mathrm{K}^{2}$. The advantage of the collector with closed foil is more obvious at higher operation temperatures. The efficiencies at a mean temperature of around $80^{\circ} \mathrm{C}$ are $51 \%, 53 \%, 54 \%$ respectively for the collector without foil, with foil with gaps and with closed foil. The difference of efficiency between the collector with and without foil is within $3 \%$. While with an increase of the mean temperature to $133^{\circ} \mathrm{C}$, the collector efficiency was decreased to $36 \%, 41 \%$ and $46 \%$ respectively. By installation of foil although with gaps, the collector efficiency will increase by $5 \%$. By sealing of leakage of the foil, the collector efficiency could further increase by another 4\%. The CPC collector has a lower collector efficiency than the XCPC measured by Widyolar et al. (2018), who obtained a collector efficiency of $50 \%$ for an operation temperature of $200^{\circ} \mathrm{C}$. The difference in collector efficiency could be explained by design of the receiver tube. The receiver tube used in the present study was uninsulated while an evacuated tube was used in the study of Widyolar et al. (2018).

Yearly thermal performance of the collectors based on aperture area was calculated for Danish climate condition using the Danish Reference Year (DRY). Based on the tangent equation of incidence angle modifier (equation 10), a coefficient (P) of 2.41 was determined by measurement and used in the calculation.

$$
k_{\theta}=1-\tan ^{P}\left(\theta_{I}\right)
$$

In equation $10, \theta_{\mathrm{I}}$ is the incidence angle in degree while $\mathrm{k}_{\theta}$ is the incidence angle modifier, [-].

The calculated thermal performances of the CPC collectors are compared to that of a typical flat plate solar collector on the market, Arcon HeatStore 35/10 (Tian et al. 2017). The efficiency expression of the collector is given in the following equation (Tian et al. 2017):

$$
\eta=0.745-2.067 *\left(\mathrm{~T}_{\mathrm{m}}-\mathrm{T}_{\mathrm{a}}\right) \boldsymbol{G}_{\mathrm{t}}-0.009 *\left(\mathrm{~T}_{\mathrm{m}}-\mathrm{T}_{\mathrm{a}}\right)^{2} / \boldsymbol{G}_{\mathrm{t}}
$$

Fig. 12 shows a comparison of yearly thermal performances of the different designed solar collectors. For the CPC collector without ETFE foil, the calculated annual performance is approx. $500 \mathrm{kWh} / \mathrm{m}^{2}$ when the mean solar collector temperature is $20^{\circ} \mathrm{C}$. With a typical mean operation temperature in Danish solar heating plant of $60^{\circ} \mathrm{C}$ (Furbo et al., 2018), output of the collector decreases to approx. $340 \mathrm{kWh} / \mathrm{m}^{2}$. After installation of the ETFE foil, although not air tight, the collector can produce $26 \mathrm{kWh} / \mathrm{m}^{2}$ more heat than the collector without ETFE foil, corresponding to an increase of $361 \mathrm{kWh}$ per collector. Considering a relatively lower cost of material and installation of ETFE foil, it is beneficial to install the ETFE foil in the CPC collector. 
Thermal performance of the CPC collector with ETFE foil can be further increased by $12 \mathrm{~kW} / \mathrm{m}^{2}$ by making the installation of the ETFE foil airtight. The flat plate solar collector outperforms the CPC collectors with a mean solar collector temperature lower than $90^{\circ} \mathrm{C}$. While for a temperature higher than $90^{\circ} \mathrm{C}$, the $\mathrm{CPC}$ with airtight ETFE foil has the best performance. With an increase of the operation temperature to $120^{\circ} \mathrm{C}$, the CPC collector with foil, even with a leaking installation, outperforms the flat plate solar collector. In conclusion the $\mathrm{CPC}$ collector with foil could be used with an advantage in district heating plants with a high operation temperature of $90-135^{\circ} \mathrm{C}$. Moreover, the CPC collector could be placed at the end of the collector row where there is a higher operation temperature. It should be noted that potentially design of the CPC collectors could be strongly improved in many aspects, for instance, better mirrors with a higher optical efficiency and better receivers with a lower heat loss coefficient. These improvements will significantly increase efficiency and thermal performance of the CPC collectors, thus increasing suitability of the CPC collectors for Danish solar heating plant, where the operation temperature lies in the range $40-80^{\circ} \mathrm{C}$.

Also thermal advantages can be achieved for Danish conditions by increasing the collector tilt tracking principle so that the collector can face north in the mornings and evenings. Further, the collector axis can with advantage be changed to north-south and the axis can be tilted towards south.

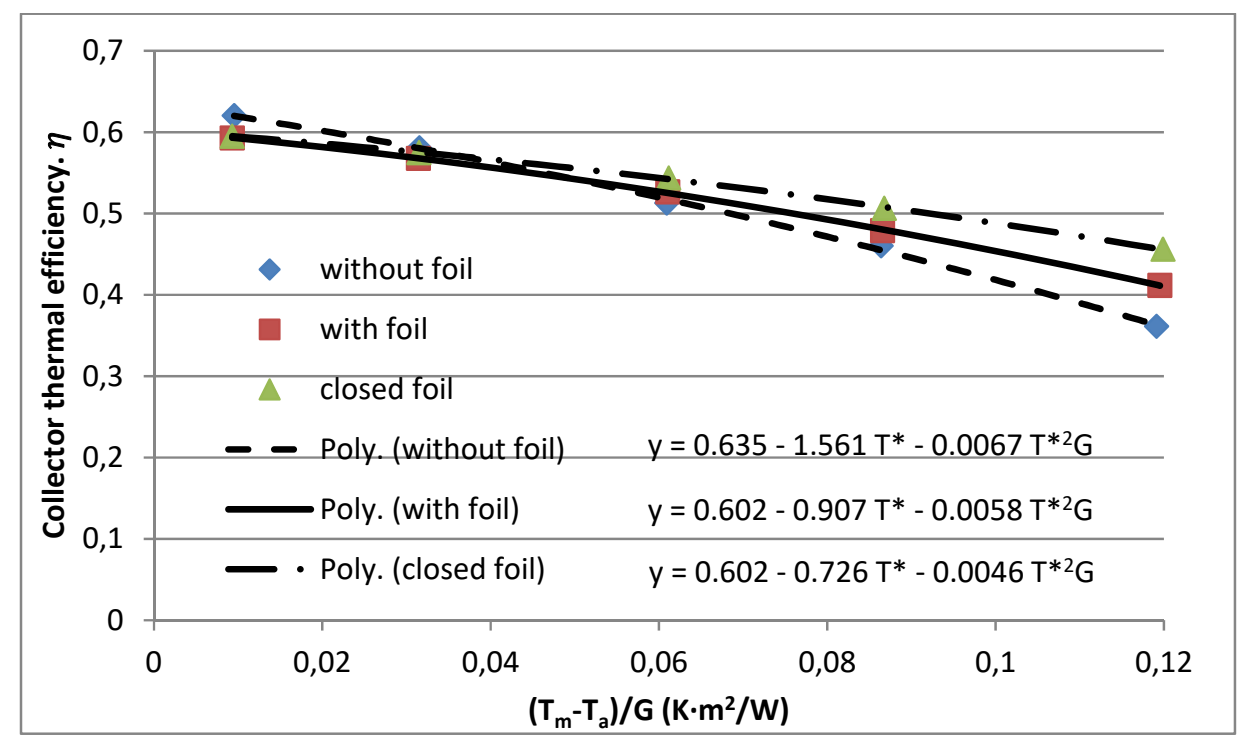


Fig. 11 CFD predicted collector efficiency expressions based on collector aperture area

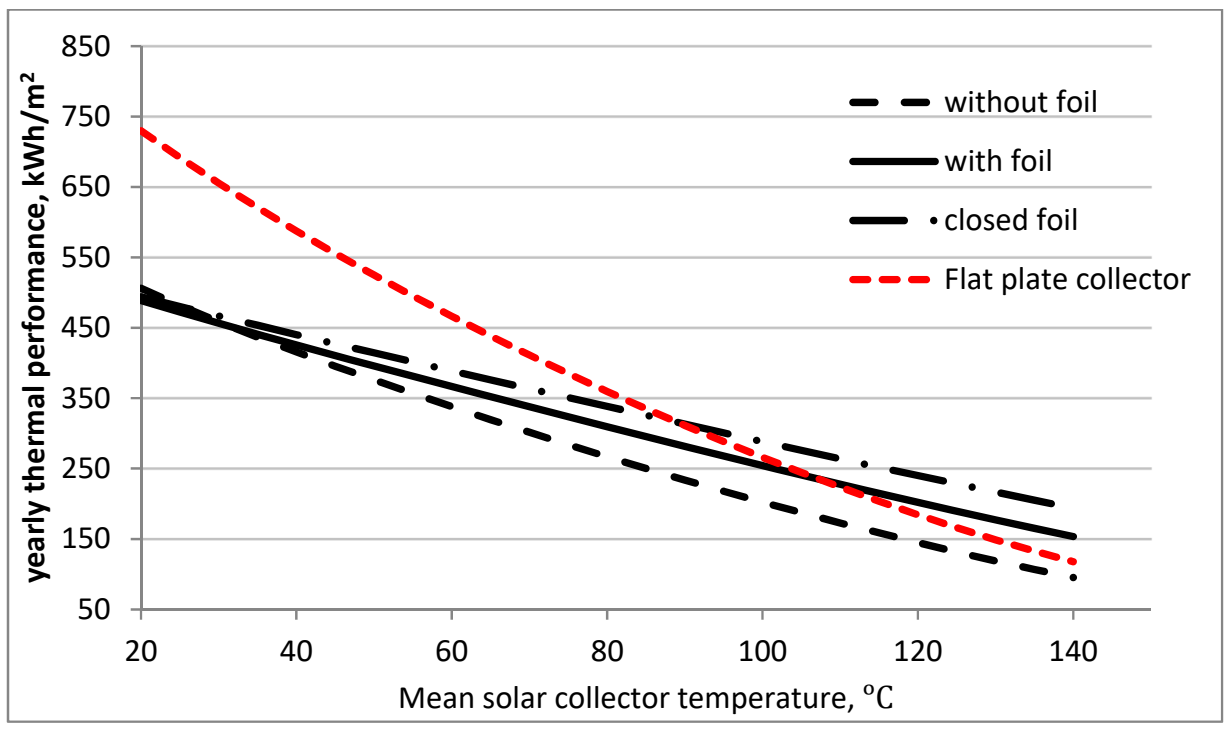

Fig. 12 Yearly thermal performance of the collectors under Danish climate condition based on collector aperture area

\section{Conclusions}

Theoretical and experimental investigations were carried out to determine thermal performance of two newly developed $15.4 \mathrm{~m}^{2}$ compound parabolic concentrator (CPC) solar collectors. The CPC solar collectors were tested for the first time in an outdoor test facility at different temperatures. CFD models of the CPC collectors were developed and validated against the measurements. The influence of the ETFE foil on collector heat loss coefficient and efficiency was investigated. The results show that efficiency of the collector with ETFE foil was measured to be $63 \%, 55 \%$ and $54 \%$ for a mean collector fluid temperature of $27^{\circ} \mathrm{C}, 63^{\circ} \mathrm{C}$ and $81^{\circ} \mathrm{C}$ respectively. The CFD model predicts satisfactorily the temperature increases of the collectors in the temperature range between $20^{\circ} \mathrm{C}$ and $81^{\circ} \mathrm{C}$. The difference between the measured and the calculated temperature rises is limited to $\pm 0.3 \mathrm{~K}$. The relative error does not exceed $3.7 \%$. The prediction error of collector efficiency by the CFD model is limited to $\pm 1 \%$.

By installation of the foil, the collector first order heat loss coefficient decreased from 1.42 to 0.82 $\mathrm{W} / \mathrm{m}^{2} \mathrm{~K}$. If the gaps were sealed, the first order heat loss coefficient could be further decreased by 0.16 $\mathrm{W} / \mathrm{m}^{2} \mathrm{~K}$. The advantage of the collector with the foil is more obvious at higher operation temperatures. With a mean collector temperature of $133{ }^{\circ} \mathrm{C}$, the collector efficiency will increase from $36 \%$ to $41 \%$ by installation of the foil. Another 5\% increase of efficiency is expected by making installation of the foil airtight. The CPC collectors with foil can outperform a typical flat plate solar collector when mean 
operation temperature of the collector is higher than $90^{\circ} \mathrm{C}$, therefore could be used with an advantage in old fashioned district heating plants or industrial applications with operation temperatures between 90$135^{\circ} \mathrm{C}$. Design of the CPC collectors has to be further improved if the collectors should be used in low temperature district heating plants as in Denmark.

\section{NOMENCLATURE}

$\mathrm{A}_{\text {collector }}$
$\mathrm{A}_{\text {absorber }}$
$\mathrm{C}_{\mathrm{p}}$
$\mathrm{C}_{\text {acc-opt }}$
$\mathrm{F}$
$\mathrm{G}_{b}$
$G_{d}$
$G_{t}$
$\mathrm{I}_{\text {tube }}$
$\mathrm{k}$
$\mathrm{k}_{\theta}$
$\dot{m}$
$\mathrm{P}$
$\mathrm{S}$
$\mathrm{T}$
$\mathrm{T}^{*}$
$T_{a}$
$T_{f i}$
$T_{f o}$
$T_{m}$

Transparent area of the collector, $\mathrm{m}^{2}$

Absorber surface area, $\mathrm{m}^{2}$

Collector fluid specific heat, $\mathrm{J} / \mathrm{kg} / \mathrm{K}$

Optical correction coefficient of the collector, [-]

Concentration factor, [-]

Beam solar irradiance, $\mathrm{W} / \mathrm{m}^{2}$

Diffuse radiation, $\mathrm{W} / \mathrm{m}^{2}$

Total radiation, $\mathrm{W} / \mathrm{m}^{2}$

Absorbed solar energy on absorber surface, $\mathrm{W} / \mathrm{m}^{2}$

Collector fluid thermal conductivity, $\mathrm{W} / \mathrm{m} / \mathrm{K}$

Incidence angle modifier, [-]

Collector fluid flow rate, $\mathrm{kg} / \mathrm{s}$

Coefficient of the tangent equation of IAM, [-]

Solar intensity on the absorber surface, $\mathrm{W} / \mathrm{m}^{2}$

Collector fluid temperature, $\mathrm{K}$

Modified collector temperature, $\mathrm{K} \cdot \mathrm{m}^{2} / \mathrm{W}$

Ambient air temperature, ${ }^{\circ} \mathrm{C}$

Collector inlet fluid temperature, ${ }^{\circ} \mathrm{C}$

Collector outlet fluid temperature, ${ }^{\circ} \mathrm{C}$

Mean collector fluid temperature, ${ }^{\circ} \mathrm{C}$

Greek symbols

$\Delta \mathrm{T}$
$\alpha_{\text {tube }}$
$\eta$
$\theta$
$\theta_{\mathrm{I}}$
$\mu$
$\rho$
$\tau_{\text {glass }}$
$\tau_{\text {foil }}$

Abbreviations
CFD

$\mathrm{CPC}$

CPV

ETC

ETFE

FPC

IAM

LCA
Collector temperature rise, $\mathrm{K}$

Absorptance of the selective coating surface, [-]

Collector efficiency, [-]

Angle along perimeter of the receiver tube, ${ }^{\circ}$

Incidence angle, ${ }^{\circ}$

Collector fluid viscosity, $\mathrm{kg} / \mathrm{m} / \mathrm{s}$

Collector fluid density, $\mathrm{kg} / \mathrm{m}^{3}$

Transmittance of the glass cover, [-]

Transmittance of the foil, [-]

Computational fluid dynamics

Compound parabolic concentrator

Concentrator photovoltaics

Evacuated tubular collectors

Ethylene tetrafluoroethylene

Flat plate collectors

Incidence angle modifier

Life cycle analysis 


$\begin{array}{ll}\text { LFR } & \text { Linear fresnel reflector } \\ \text { meas. } & \text { Measurement } \\ \text { ORC } & \text { Organic Rankine Cycle } \\ \text { PRESTO } & \text { PREssure STaggering Option } \\ \text { PTC } & \text { Parabolic-trough collector } \\ \text { PVT } & \text { Photovoltaic thermal } \\ \text { SIMPLE } & \text { Semi-implicit method for pressure-linked equations } \\ \text { sim. } & \text { Simulation } \\ \text { XCPC } & \text { External compound parabolic concentrator }\end{array}$

\section{Acknowledgement}

This work was supported by the National Natural Science Foundation of China (51476164), Guangdong Innovative and Entrepreneurial Research Team Program (No.2013N070) and China Scholarship Council (CSC No. 201504910175). The work was also supported by the Danish Energy Agency through the project: Pilot installation of hybrid solar collectors in district heating plants (journal number 64015-0595) within the Energy Technology Development and Demonstration Program, EUDP. Finally, the research came to existence thanks to kind sponsorship of the company PolyCSP ApS.

\section{References}

[1] Abdullahi B., AL-Dadah R.K., Mahmoud S., Hood R. Optical and thermal performance of double receiver compound parabolic concentrator. Applied Energy 159 (2015) 1-10.

[2] Ansys Inc., 2016. Ansys Fluent release 17.0, Southpointe, 2600, Ansys Drive, Canonsburg, PA 15317, USA.

[3] Antonelli M., Francesconi M., Marco P.D., Desideri U. Analysis of heat transfer in different CPC solar collectors: A CFD approach. Applied Thermal Engineering 101 (2016) 479 - 489

[4] Antonin A., Stefancich M., Coventry J., Parretta A. Modelling of Compound Parabolic Concentrators for Photovoltaic Applications. International Journal of Optics and Applications 3(4) (2013): 40-52

[5] Arunkumar T., Velraj R., Denkenberger D.C.. Productivity enhancements of compound parabolic concentrator tubular solar stills. Renewable Energy 88 (2016) 391-400

[6] Atheaya D., Tiwari A., Tiwari G.N., Al-Helal I.M. Performance evaluation of inverted absorber photovoltaic thermal compound parabolic concentrator (PVT-CPC): Constant flow rate mode. Applied Energy 167 (2016) 70-79. 
[7] Blanco M.J., Amievas J.M., Mancilla, 2005. The Tonatiuh Software Development Project: An Open Source Approach to the Simulation of Solar Concentrating Systems. ASME International Mechanical Engineering Congress and Exposition, pp. 157-164.

[8] Blanco, M.J., Mutuberria A., Monreal A., Albert R., 2011. Results of the empirical validation of Tonatiuh at Mini-Pegase CNRS-PROMES facility. 17th SolarPACES Conference, 20 - 23 September 2011, Granada, Spain.

[9] Cioccolanti L., Rajabi Hamedani S., Villarini M. Environmental and energy assessment of a small-scale solar Organic Rankine Cycle trigeneration system based on Compound Parabolic Collectors. Energy Conversion and Management 198 (2019) 111829.

[10] Craig K.J., Moghimi M.A., Rungasamy A.E., Marsberg J., Meye J.P. Finite-volume ray tracing using Computational Fluid Dynamics in linear focus CSP applications. Applied Energy 183 (2016) 241-256.

[11] Devanarayanan K., Kalidasa Murugavel K. Integrated collector storage solar water heater with compound parabolic concentrator - development and progress. Renewable and Sustainable Energy Reviews 39(2014) $51-64$.

[12] Esen M., Esen H., Experimental investigation of a two-phase closed thermosyphon solar water heater. Solar Energy, 79(2005) 459-468.

[13] Fan J., Furbo S. Buoyancy effects on thermal behavior of a flat-plate solar collector. Journal of Solar Energy Engineering, 130(2008), 021010.

[14] Fan J., Louise Jivan S., Furbo S. Flow distribution in a solar collector panel with horizontally inclined absorber strips. Solar Energy, 81(2007), 1501-1511.

[15] Feng C., Zheng H., Wang R., Yu X. Su Y. A novel solar multifunctional PV/T/D system for green building roofs. Energy Conversion and Management, 93 (2015) 63-71.

[16] Francesconi, M.; Caposciutti, G.; Antonelli, M. CFD optimization of CPC solar collectors. Energy Procedia, 148 (2018) 551-558.

[17] Furbo S., 1997. "Varmelagre til solvarmeanlæg”, Institut for Bygninger og Energi, Technical University of Denmark, 22-23.

[18] Furbo S., Dragsted J., Perers B., Andersen E., Bava F., Nielsen K.P. Yearly thermal performances of solar heating plants in Denmark - Measured and calculated, Solar Energy 159 (2018) 186-196.

[19] Garrison J. D. Optimization of a fixed solar thermal collector. Solar Energy, 23 (1979) 93-102. 
[20] Jafrancesco D., Sani E., Fontani D. Simple methods to approximate CPC shape to preserve collection efficiency. International Journal of Photoenergy. 2012 (2012), 1-7.

[21] Khonkar H.E.I., Sayigh A.A.M. Raytrace for compound parabolic concentrator. Renewable Energy, 5 part I (1994), 376-383.

[22] Kong W., Furbo S., Perers B., \& Englmair G. Thermal performance analysis of a CPC solar collector array with series connection to the flat plate solar collector field in Sæby solar heating plant, ISES Solar World Congress 2019 and IEA SHC conference 2019, November 4-7, 2019, Santiago, Chile.

[23] Kumar L., Hasanuzzaman M., Rahim N. A. Global advancement of solar thermal energy technologies for industrial process heat and its future prospects: A review. Energy Conversion and Management 195 (2019) 885-908.

[24] Madala S., Boehm R. F. A review of nonimaging solar concentrators for stationary and passive tracking applications. Renewable and Sustainable Energy Reviews, 71 (2017) 309-322.

[25] Morrison GL, 2001, Solar Collectors, in Gordon J (ed.), Solar Energy: The State of the Art, edn. Original, James \& James (Science Publishers) Ltd, United Kingdom, 166-168.

[26] Nussbaumer T., Thalmann S., 2014, Status report on district heating systems in IEA concountries, Zurich, Switzerland, ISBN 3-908705-28-2.

[27] Osório T., Horta P., Collares-Pereira M. Method for customized design of a quasi-stationary CPC-type solar collector to minimize the energy cost. Renewable Energy, 133 (2019) 1086-1098.

[28] Pranesh, V.; Velraj, R.; Christopher, S.; Kumaresan, V. A 50 year review of basic and applied research in compound parabolic concentrating solar thermal collector for domestic and industrial applications. Solar Energy, 187 (2019) 293-340.

[29] Rabl A., Goodman N.B., Winston R. Practical design considerations for CPC solar collectors. Solar Energy, 22(1979), 373-381.

[30] Sallaberry F., Kong W., Furbo S., et al. Suitability of the accuracy of a tracking system with a CPC solar collector acceptance angle, Solar PACES, September 26-29, 2017, Santiago, Chile.

[31] Santos-González I., Sandoval-Reyes M., García-Valladares O., Ortega N., Gómez V.H. Design and Evaluation of a Compound Parabolic Concentrator for Heat Generation of Thermal Process. Energy Procedia 57 (2014) $2956-2965$.

[32] Tian Z., Perers B., Furbo S., Fan J. Annual measured and simulated thermal performance analysis of a 
hybrid solar district heating plant with flat plate collectors and parabolic trough collectors in series, Applied Energy, 205 (2017) 417-427.

[33] Tian Z., Perers B., Furbo S., Fan J., Analysis and validation of a quasi-dynamic model for a solar collector field with flat plate collectors and parabolic trough collectors in series for district heating. Energy, 142 (2018) 130-138.

[34] Tian Z., Perers B., Furbo S., Fan J., Thermo-economic optimization of a hybrid solar district heating plant with flat plate collectors and parabolic trough collectors in series. Energy Conversion and Management, 165 (2018) 92-101.

[35] Tian M., Su Y., Zheng H., Pei G., Li G., Riffat S. A review on the recent research progress in the compound parabolic concentrator (CPC) for solar energy applications. Renewable and Sustainable Energy Reviews, 82 (2018) 1272-1296.

[36] Tian Z., Zhang S., Deng J., Fan J., Huang J., Kong W., Perers B. \& Furbo S., Large-scale solar district heating plants in Danish smart thermal grid: Developments and recent trends. Energy Conversion and Management, 189 (2019) 67-80.

[37] Umair M., Akisawa A., Ueda Y. Performance Evaluation of a Solar Adsorption Refrigeration System with a Wing Type Compound Parabolic Concentrator. Energies 7 (2014) 448-1466

[38] Varghese J., Manjunath K. A parametric study of a concentrating integral storage solar water heater for domestic uses. Applied Thermal Engineering, 111 (2017), 734-744.

[39] Welford W.T., Winston R., 1978, The optics of nonimaging concentrators. Light and solar energy, Academic Press, pp. 200s.

[40] Widyolar B., Jiang L., Ferry J., Winston R. Non-tracking East-West XCPC solar thermal collector for 200 celsius applications. Applied Energy, 216 (2018) 521-533.

[41] Winston R., Principle of solar concentrators of a novel design. Solar Energy 16 (1974) 89-95.

[42] Zheng W., Yang L., Zhang H. You S., Zhu C. Numerical and experimental investigation on a new type of compound parabolic concentrator solar collector. Energy Conversion and Management 129 (2016) 11-22. 